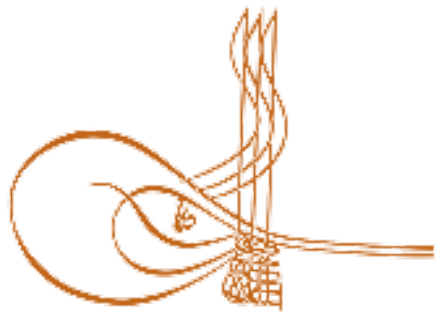

www.turkishstudies.net/education
Turkish Studies - Educational Sciences

eISSN: $2667-5609$

Research Article / Araștırma Makalesi

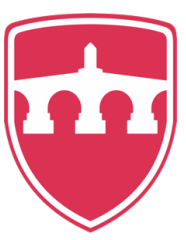

INTERNATIONAL

BALKAN

UNIVERSITY

Sponsored by IBU

\title{
Okul Öncesi Öğretmenlerinin Çocuk İhmal ve İstismarı ile Çocuk Haklarına Yönelik Görüşleri ${ }^{1}$
}

\author{
Opinions of Preschool Teachers Regarding Child Negligence and Abuse and Child Rights ${ }^{2}$
}

\author{
Pınar Bağçeli Kahraman* Büşra Doğan** ${ }^{*}$ Murat Şimşek***
}

\begin{abstract}
In this research it is aimed to evaluate knowledge and experiences of teacher candidates regarding child negligence and abuse and child rights. Case study that aims to give prominence to self-experiences of individuals was used in the research. Snowball sampling method, which is one of the purposive sampling methods, was used for the determination of participants. The sample of the research consists of 20 preschool teachers. 10 teachers had been working for two years at least and five of them work at private schools and other five teachers work in public schools. Also 10 teachers from this group were newly graduated from Education Faculty Preschool Education Department in 2018-2019 education year. Five of these newly graduate teachers work at private schools and other five teachers work at public schools. Interview technique, which is one of the qualitative research techniques, was used in this research. Teachers participated in the research voluntarily and they signed the consent information form. Also in the research teachers were given codes instead of their names and their information was kept confidential. "Semi Structured Teacher Interview Form That Determines Experiences of Preschool Teachers Regarding Child Negligence and Abuse" was carried out. When semi structured interview form was prepared, first of all a draft form was prepared, which consists of questions regarding child negligence and abuse and child rights. Draft form took its final shape after taking views of two experts specialized in the field of child rights. Finally pilot scheme was carried out with two preschool teachers
\end{abstract}

${ }^{1}$ Çalışma 2018-2019 eğitim-öğretim yılında yürütülmüştür.

2 This study was conducted in 2018-2019 education year.

* Doç. Dr. Bursa Uludağ Üniversitesi, Temel Eğitim Bölümü, Okul Öncesi Eğitimi ABD.

Assoc. Prof. Dr. Bursa Uludag University, Education Faculty, Department of Basic Education, Preschool Education Program.

ORCID 0000-0002-0551-7741

pinarbag@uludag.edu.tr

**Yüksek Lisans Öğrencisi, Bursa Uludağ Üniversitesi, Okul Öncesi Eğitimi Bilim Dalı

Master Degree Student, Bursa Uludag University, Institute of Educational Sciences, Department of Basic Education,

Preschool Education Program.

ORCID 0000-0002-6684-1115

***Yüksek Lisans Öğrencisi, Bursa Uludağ Üniversitesi, Okul Öncesi Eğitimi Bilim Dalı

Master Degree Student, Bursa Uludag University, Institute of Educational Sciences, Department of Basic Education,

Preschool Education Program.

ORCID 0000-0003-3210-0244

Cite as/ Atıf: Bağçeli Kahraman, P., Doğan, B \& Şimşek, M. (2020). Okul öncesi öğretmenlerinin çocuk ihmal ve istismarı ile çocuk haklarına yönelik görüşleri, Turkish Studies- Education, 15(2), 691-715. https://dx.doi.org/10.29228/TurkishStudies.40135

Received/Geliş: 12 December/Aralık 2019

Accepted/Kabul: 23 April/Nisan 2020

Checked by plagiarism software

Copyright (C) INTAC LTD, Turkey 
and form was put into practice after observing that the questions were accurate and understandable. Data was analyzed via content analysis. It was observed that the children, who suffered from abuse, mostly had social behaviour problems, then individual symptoms and behavioural problems and finally verbal behavioural problems. The teachers' possessing excessive zone within the classroom to observe the social behaviours makes the situation recognizable. It was determined that the activities performed by the teachers regarding neglect and abuse were aimed at sexual awareness, social awareness and child rights awareness. For the happiness of children teachers who believe in child rights and who are educated well in this field, are required. It is thought that in order to realise this situation, teacher candidates must be given an education and also teachers must be given in service trainings regarding child negligence and abuse and child rights.

Structured Abstract: Introduction: Teachers play a quite important role in determining and preventing child negligence and abuse. Because, teachers can easily determine physical and behavioral changes of the child. In addition it is thought that teaching children their rights at an early period is an important precaution for preventing negligence and abuse. It is thought that the children who know their rights can protect themselves better and they can choose to cope with the negative situations they experience. Pekdoğan and Bozgün (2018) state that teachers have an important place in being responsible from education of children in addition to sharing the problems of children who were subjected to abuse and negligence and also finding solutions for these problems before they increase. Child rights are laws protected by legal rules in order to provide children grow up in freedom and dignity in physical, mental, emotional, social and moral aspects, and also enable them develop normally and healthily (Aral \& Gürsoy, 2001). Washington (2010), state that via child rights education, children become prepared for being together with adults and other children in their families and individual relationships. It is thought that teaching children their rights during preschool education, in which fundamental education is provided, is important in terms of raising awareness and preventing negative situations. In this research it is aimed to evaluate views of teacher candidates regarding child negligence and abuse and child rights. However within the frame of child rights a study, in which negligence and abuse are evaluated according to preschool teachers' opinions, was not found. For this purpose answers were searched for the research questions below:

1. What are the opinions of preschool teachers regarding child negligence and abuse?

2. What are the opinions of preschool teachers regarding child rights?

\section{Method}

Holistic multi case study, which is one of the case study types, was used in this research. In holistic multi case studies every case is selected carefully, whether similar results are obtained or not is examined, separate reports are prepared for every case and final report is prepared comparatively (Akar, 2017). In this study researchers focused on determination of how teachers working at public and private schools experienced the process on the basis of the opinions of teachers regarding child negligence and abuse and child rights. Snowball sampling method, which is one of the purposive sampling methods, was used for the determination of participants. 10 teachers from this group newly graduated from Education Faculty Preschool Education Department in 2018-2019 education year. Five of these newly graduate teachers work at private schools and other five teachers work at public schools. Teachers participated in the research voluntarily and they signed the consent information form. Teachers were given codes instead of their names and their information was kept confidential. "Semi Structured Interview Form Determining Experiences of Preschool Teachers Regarding Child Negligence and Abuse and Child Rights" was used. When semi structured interview form was prepared, first of all a draft form was prepared, which consists of questions regarding child negligence and abuse and child rights. Draft form took its final shape after taking views of two experts specialized in the field of child rights. Finally pilot scheme was carried out with two preschool teachers and form was put into practice after observing that the questions were accurate and understandable. Interviews took almost 35 minutes. Data was analyzed with content analysis method.

\section{Conculusion and Suggestion}

When the teachers were asked about the definition and the types of the neglect it was seen that they associated the neglect with responsibility and care concepts. It can be said that the teachers, who participated in the study, had ideas regarding neglect; however they had difficulties in making an exact definition. As a 
result of the research it was seen that the teachers, who took education regarding neglect and abuse, could make more explanatory definitions. It was seen that preschool teachers stated their opinions about child negligence in definition and types subthemes and also they connected negligence with responsibility and care concepts more. When their answers regarding types of negligence are examined it was seen that teachers mostly gave responds regarding emotional, physical, education/educational, social and economic negligence respectively. When types of negligence are examined it is seen that they are physical, emotional and sexual negligence. However teachers who participated in the study did not make any statements about sexual negligence. In the circumstances it can be concluded that teachers cannot distinguish sexual negligence and sexual abuse from one another. It can be stated that teachers who participated in the study had opinions about negligence however they had difficulties in making an exact definition. When the views of teachers about the child abuse are examined it was determined that they made statements mostly about using force, emotional pressure, taking advantage and damaging subthemes respectively. It was seen that teachers had opinions about abuse however they had difficulty in making definition. When their responds given to types it was seen that teachers made statements regarding physical, emotional and sexual abuse in addition to teachers who mentioned abuse types such as economic, social, psychological and drug addiction. According to the opinions of preschool teachers it was observed that children, who were assumed to be abused, mostly had internalization behavior problems and then externalization behavior problems.

It was determined that activities teachers applied regarding negligence and abuse were aimed at sexual awareness, social awareness and child rights. However teachers' failure to tell the difference between sexual negligence and abuse is thought provoking considering whether they have adequate knowledge about the activities. It is seen that teachers do not include applications regarding child rights adequately and their knowledge about child rights is limited. For the happiness of children teachers who believe in child rights and who are educated well in this field, are required. It is thought that in order to realize this situation, teacher candidates must be given an education and also teachers must be given in service trainings regarding child negligence and abuse and child rights. It can be stated that combining the contents of this education and training with activities that can be performed with children is important for teachers providing an education in a more easily and convenient way. Within the context of this research, only opinions of teachers are considered. Studies that involve teachers' in-class applications can be carried out. Conducting experimental studies regarding the protection of children from child negligence and abuse including child rights is important in terms of seeing how this matter can be developed in preschool education.

Keywords: Preschool Education, Child Neglect And Abuse, Child Rights, Preschool Teachers, Interview.

Öz: Bu araştırmada okul öncesi öğretmenlerinin çocuk ihmal ve istismar ile çocuk haklarına yönelik bilgi ve deneyimlerinin değerlendirilmesi amaçlanmıştır. Araştırmada bireylerin kendi deneyimlerini ön plana çıkarmayı amaçlayan durum çalışması kullanılmıştır. Araştırmada amaçlı örnekleme tekniklerinden kartopu örneklemesi kullanılmıştır. Araştırmanın örneklemini, 2018-2019 eğitim öğretim yılında Eğitim Fakültesinin Okul Öncesi Eğitimi Anabilim Dalından yeni mezun olmuş ve beşi özel, beşi devlet anaokulunda çalışmakta olan 10 okul öncesi öğretmeni ile en az iki yıldır beşi özel, beşi devlet anaokulunda çalışmakta olan 10 okul öncesi olmak üzere toplam 20 okul öncesi öğretmeni oluşturmaktadır. Bu araştırmada nitel araştırma tekniklerinden görüşme tekniği kullanılmıştır. Öğretmenler araştırmaya gönüllü olarak ve onam formunu imzalayarak katılmışlardır. Öğretmenlere isimleri yerine kodlar verilmiş ve bilgileri gizli tutulmuştur. Öğretmenlere "Okul Öncesi Öğretmenlerin Çocuk İhmal ve İstismarı ile Çocuk Haklarına Yönelik Deneyimlerini Belirleyen Yarı Yapılandırılmış Öğretmen Görüşme Formu” uygulanmıştır. Görüşme formu hazırlanırken öncelikle çocuk ihmal ve istismarı ile çocuk haklarına ilişkin sorulardan oluşan bir taslak form hazırlanmıştır. Öğretmenlerin çocuk ihmal ve istismarına ilişkin görüş ve deneyimlerinin belirlenmesine yönelik hazırlanan bu taslak formda sekiz soru sorulmuştur. Taslak form çocuk hakları alanında uzman iki kişinin görüşleri alınmış ve değiştirilmeden son halini almıştır. Uzman görüşlerine göre soruların kapsam geçerliği olduğu söylenebilir. Araştırma kapsamı dışında tutulan iki okulöncesi öğretmeni ile pilot uygulama yapılmış, soruların açık ve anlaşılır olduğu görülerek form uygulamaya konmuştur. Veriler içerik analizi yoluyla analiz edilmiştir. İstismara uğradığı düşünülen çocuklarda en çok sosyal davranış problemleri ardından bireysel belirtiler ve davranış problemleri, en son olarak sözel davranış problemleri olduğu gözlemlenmiştir. Öğretmenlerin sınıf içinde sosyal davranışları gözlemleyebileceği çok fazla alanın olması bu durumu anlaşılır kılmaktadır. Öğretmenlerin ihmal ve istismar hakkında uyguladıkları etkinliklerin cinsel farkındalığa yönelik, 
sosyal farkındalığa yönelik ve çocuk haklarına yönelik olduğu belirlenmiştir. Çocukların mutluluğu için çocuk haklarına inanan ve bu konuda iyi eğitim almış öğretmenlere ihtiyaç vardır. Bu durumun gerçekleşebilmesinde öğretmen adaylarına öğretmenlik eğitimleri süresince çocuk hakları ile ihmal ve istismara yönelik bir eğitimin verilmesinin ve öğretmenlere hizmet içi eğitimlerin verilmesi gerektiği düşünülmektedir.

Anahtar Kelimeler: Okul Öncesi Eğitim, Çocuk İhmali ve İstismarı, Çocuk Hakları, Okul Öncesi Öğretmeni, Görüşme.

\section{Giriş}

Çocuklar, 18 yaşını doldurmamış, en önemli gereksinimi güvenlik, bakım, beslenme ve sevgi olan, büyüyüp gelişen ve topluma katılan bireylerdir. Çocukların bu gereksinimlerinin giderilmesinde ve desteklenmesinde anne ve babalarına ya da onlara bakan kişilere büyük görev düşmektedir (Topçu, 2009; Üstündağ, Şenol \& Mağden, 2015). Ancak çocuğun bu doğal ihtiyaçlarını karşılamayan aile ya da çocuğa bakmakla yükümlü olan kişiler de var olmaktadır. Ailenin ya da çocuğa bakmakla yükümlü olan kişinin, çocuğun bakım, beslenme, barınma, giyim, eğitim, sevgi ve güven gibi en temel ihtiyaçlarını yerine getirmemesi çocuk ihmali şeklinde tanımlanmaktadır. İhmal, fiziksel, cinsel ve duygusal ihmal olarak ayrilabilmektedir. Fiziksel ihmal çocuğun yeterince beslenmemesi, temizliğine özen verilmemesi, yetersiz fiziksel çevrede yaşaması, ev içi ve diş1 kazalardan korunmaması durumu; duygusal ihmal ise çocuğa ilgi ve sevgi gösterilmemesi, güvenliğinin sağlanmaması, destek ve denetimden yoksun bırakılması durumu; cinsel ihmal ise çocukların cinsel istismara yönelik bilgilendirilmemesi, konuya karşı duyarsız davranılması ve cinsel gelişime gerekli önemin gösterilmemesi durumu olarak karşımıza çıkmaktadır (Durmuşoğlu-Saltalı, 2015; Kurtoğlu 2016; Topçu 2009 ).

Dünya Sağlık Örgütü (2002) çocuğun psikososyal ve fiziksel gelişimi ile sağlığını olumsuz olarak etkilemesine neden olan bilerek veya bilmeyerek bir yetişkin, toplum ya da yetiştiği ülke tarafından yapılan tüm davranışları çocuk istismarı olarak tanımlamaktadır. Çocuk istismarı cinsel, duygusal, fiziksel ve ekonomik istismar olarak dört boyutta incelenmektedir (Topçu, 2009; Yalçın, Koçak \& Duman, 2014). Fiziksel istismar, çocuğun gelişiminde ya da vücudunda zedelenmelere, geçici ya da sürekli hasara yol açan her türlü davranıştır. En sık rastlanan ve en kolay tanınan istismar biçimidir (Topçu, 2007). Araştırmalar ailelerin ve öğretmenlerin problem çözme yöntemi olarak yüksek oranlarda tehdit, kıyaslama ve yargılama davranışları ve şiddete başvurduklarını göstermektedir (Banko, 2017; Dereobalı, Karadă̆ \& Sönmez, 2013; Oral, Engin \& Büyükyazıc1, 2010).

Cinsel istismar, gelişimsel olarak hazır olmayan bir çocukla erişkinin ya da gencin toplumsal yasakları ve yasaları çiğneyerek cinsel ilişki kurması olarak tanımlanabilir (Topçu, 2009). Cinsel istismardan en fazla zarar gören çocukların 0-11 yaş aralığında olduğu da belirtilmektedir (Bilginer, Hesapcioglu \& Kandil, 2013; Durmuşoğlu-Saltal1, 2014; Kucuk, 2016; Kurtoğlu, 2016). Her yaşta ve sosyoekonomik gruptaki çocuklar cinsel istismara maruz kalmaktadır. Yapılan araştırmalar çocukların yaşadıkları cinsel istismar durumlarını öğretmenleriyle paylaştıklarını da göstermektedir (Kenny \& McEachern, 2008).

Duygusal istismar, çocuğun yaşantısında diğer kişilerle etkileşimde bulunurken gösterdiği davranışları eleştirerek, küçük düşürerek ya da cezalandırarak, çocuğun kendilik değerini, yeterliğini, bağlılık duygusunu zedelemek ya da belirgin bir şekilde çocuğa zarar vermektir (Belsky, 1980: Akt. Polat, 2007; Yenibaş \& Şirin, 2007). Her istismar yaşantısında birey duygusal olarak da zarar görmektedir (Pears, Kim \& Fisher, 2008). Ekonomik istismar ise, çocuğun gelişimini engelleyen ve haklarını ihlal eden işlerde çalışması ya da başkası tarafından çalıştırılmasıdır (Kurtoğlu, 2016).

Çocukların ihmal ve istismardan korunabilmesinde ve çocuğa yapılan bu kötü muamalelerin önüne geçilebilmesinde çocukların ve toplumdaki diğer insanların çocuk haklarını bilmesinin önemli 
olduğu düşünülmektedir. Çocuk hakları, çocukların sahip oldukları eğitim, barınma, sağlık, psikolojik ve fiziksel hakların tamamını içermektedir. 1924 yılında hazırlanan Çocuk Hakları Bildirgesine dayanmakla birlikte, 1989 yılında imzalanan Birleşmiş Milletler Çocuk Hakları Sözleşmesi ile tüm dünyada daha fazla dikkate alınmaya başlanmıştır. Türkiye ise 1990 y1lında bu sözleşmeyi imzalamış ve 1995 yılından itibaren uygulamaya başlamıştır. Bu sözleşme, çocukların istismar ve ihmale maruz kalmaması yanında gelişme, sağlıklı büyüme ve eğitim olanaklarına sahip olması, huzurlu ve mutlu olmasını içeren maddelerden oluşmaktadır. Çocukların bu haklarının bilinerek korunması, bu haklara saygı gösterilmesi ancak eğitim yoluyla olmaktadır (Erbay, 2013; Gökler, 2009; Turupcu \& Gültekin Akduman, 2015; Yıldırım-Doğru, 2015).

Bronfenbrenner'in $(1979,1989$ : Akt. Bee, 1995) Ekolojik Kuramı çocuğun kardeş, ebeveyn, dede-nine, hayvanlar, okul ve arkadaşlar gibi karmaşı sosyal bir çevre içinde gelişmekte olduğunu belirtmektedir. Breadkamp ve Copple'ın (2002) belirttiğine göre; çocuğun gelişimi en iyi aile, eğitim, toplum bağlamında açıklanabilmektedir. Bu nedenle ailenin ve aileden sonra ilk eğitimcileri olan okul öncesi öğretmenlerinin çocuğa verdiği eğitim çocuğun sağliklı büyüme, gelişme ve eğitim olanaklarına sahip olmasında önemlidir. Ayrıca okul öncesi öğretmenleri çocuklarla uzun süre geçirmekte ve çocukları diğer öğretmenlere göre daha iyi tanıyabilmektedirler (McKee \& Dillenburger, 2012).Bu nedenle çocuk ihmalini ve istismarını belirlemede ve önlemede okul öncesi öğretmenlerin önemi oldukça büyüktür. Çünkü çocukta meydana gelen fiziksel ve davranışsal değişiklikleri en kolay şekilde öğretmenler belirleyebilmektedir. Ancak yapılan araştırmalar da ögretmenlerin ihmal ve istismarı tanılamada ve bildirmede yetersiz olduklarını göstermektedir (Aksel \& Irmak, 2015; Banko, 2017; Bourke \& Maunsell, 2016; Buckley \& McGarry, 2011, Kenny, 2004; Márquez-Floresa, Márquez-Hernándezb \& Granados-Gámezb,2016; Münger \& Markström, 2019; Toros \& Tiirik, 2016; Walsh, Schweitze, Farrell \& Bridgstock, 2005). Uçuş ve Şahin (2012) ise çocuk haklarına ilişkin olarak öğretmenlerin ve okul yöneticilerin çok fazla bilgiye sahip olmadıklarını, ders programında sadece ele alındığı zaman öğrencilerle paylaşımda bulunduklarını saptamışlardır. Dereobalı, Karadağ ve Sönmez (2013) da yaptıkları araştırmada öğretmenlerin ihmali, istismara göre çok daha iyi tanımladıklarını ve ihmal ve istismarın önlenmesinde eğitimcilerin önemli rolü olduğu sonucuna ulaşmışlardır. Goldman (2005) da istismar yönelik farkındalığın artırılmasında öğretmenlerin alacakları eğitimlerin önemli olduğunu ve öğretmenlerin aktif olarak çocukları korumaya yönelik programların içinde yer almaları gerektiğini belirtmiştir. Pekdoğan ve Bozgün (2018) de öğretmenlerin, çocukların eğitimlerinden sorumlu olduklarını ve bununla birlikte ihmal ve istismara maruz kalan çocukların problemlerini dinleyebilmede ve bu sorunların çözülebilmesinde önemli bir yere sahip olduklarını ifade etmektedir. Çocuk hakları; çocuğun zihinsel, bedensel, sosyal-duygusal ve ahlaki olarak normal ve sağliklı bir biçimde gelişebilmesinde hukuk kuralları çerçevesinde korunan yasalardır (Aral \& Gürsoy, 2001). Washington (2010), çocuk hakları eğitimi ile çocukların toplumda, ailesinde, bireysel ilişkilerinde, yetişkinler ve diğer çocuklarla her gün bir arada olmaya hazırlandığını ifade etmektedir. Bu nedenle haklarını bilen çocukların kendilerini daha iyi koruyabilecekleri ve yaşadıkları olumsuz durumlarla baş etme yolunu seçebilecekleri de düşünülmektedir. Şallı (2017) okul öncesi öğretmenlerinin çocuk hakları konusunda sınırlı bilgilere sahip olduklarını ve sınıflarında çocuk haklarını fazla uygulamadıklarını belirlemiştir. Topçu (2019) uyguladığı drama temelli çocuk hakları eğitiminin çocukların çocuk hakları için bilgi gelişimi, çocuk haklarının önemi için farkındalık oluşumu, çocuk hakları temelli davranış gelişimi için faydalı olduğunu göstermiştir. Çocuk haklarının öğretilmesinin özellikle temel eğitimin verildiği okul öncesi eğitimde önleyici ve bilinçlendirici olması açısından önemli olduğu düşünülmektedir. Bu araştırmada okul öncesi öğretmenlerinin çocuk ihmal ve istismar ile çocuk haklarına yönelik görüşlerinden yola çıkarak bilgi ve deneyimlerinin değerlendirilmesi amaçlanmıştır. Çocuk hakları ile çocuk ihmal ve istismarının okul öncesi öğretmenlerinin görüşlerine göre değerlendirildiği bir çalışmaya da rastlanmamıştır. Bu amaç doğrultusunda aşağıdaki araştırma sorularına cevap aranmıştır: 
1. Okul öncesi öğretmenlerinin çocuk ihmal ve istismarı ile ilgili görüşleri nelerdir?

2. Okul öncesi öğretmenlerinin çocuk hakları ile ilgili görüşleri nelerdir?

\section{Alt Başlık}

\section{Yöntem}

\section{Araştırma Modeli}

Durum çalışması araştırmacının, güncel durumları çalışarak bir ya da daha fazla konu hakkında derinlemesine bilgi sağlamasını ve betimleyerek bu durumları ortaya koymasını amaçlayan çalışmalardır (Creswell, 2016; Yin, 2013). Bu araştırmada durum çalışması türlerinden bütüncül çoklu durum çalışması kullanılmıştır. Bütüncül çoklu durum çalışmalarında her durum dikkatlice seçilerek benzer sonuçların var olup olmadığı incelenir ve her duruma ayrı rapor hazırlanarak karşılaştırmalı son rapor oluşturulur (Akar, 2017). Bu çalışmada da deneyimli ve yeni mezun özel ve devlette çalışan okul öncesi öğretmenlerin çocuk ihmal ve istismarı ile çocuk haklarına yönelik görüşlerinden yola çıkarak, süreci nasıl deneyimlediklerinin belirlenmesine odaklanılmıştır.

\section{Çalışma Grubu}

Araştırmanın çalışma grubu amaçlı örnekleme yöntemlerinden kartopu örnekleme ile belirlenmiştir. Çalışmada kimin daha çok şey bileceği ve kimle görüşülmesi gerektiği (Patton,1987) düşüncesinden yola çıkılarak, öğretmenlerin yönlendirmeleri doğrultusunda çalışma grubu belirlenmiştir. Bu yaklaşım ile araştırmacılar problemlerine ilişkin zengin bilgi kaynakları olabilecek bireyleri saptanma yoluna gitmişlerdir (Yıldırım \& Şimşek, 2011). Araştırmanın örneklemini, 20182019 eğitim öğretim yılında Eğitim Fakültesinin Okul Öncesi Eğitimi Anabilim Dalından yeni mezun olmuş ve beşi özel, beşi devlet anaokulunda çalışmakta olan 10 okul öncesi öğretmeni ile en az iki yıldır beşi özel, beşi devlet anaokulunda çalışmakta olan 10 okul öncesi olmak üzere toplam 20 okulöncesi öğretmeni oluşturmaktadır. Çalışmada öğretmenlerin isimleri değiştirilmiştir. Öğretmenlerin demografik bilgileri Tablo 1'de verilmiştir.

Tablo 1:Demografik Bilgiler

\begin{tabular}{llll}
\hline \multicolumn{1}{c}{ Öğretmenin Adı } & Okul Türüi & Deneyim & $\begin{array}{l}\text { İhmal ve İstismar İle İlgili } \\
\text { Eğitim Alma Durumu }\end{array}$ \\
\hline Filiz & Devlet & Deneyimsiz & Var (Üniversitede Ders) \\
Esma & Devlet & Deneyimsiz & Yok \\
Melike & Devlet & Deneyimsiz & Yok \\
Kevser & Devlet & Deneyimsiz & Yok \\
Hülya & Devlet & Deneyimsiz & Var (Üniversitede Ders) \\
Esra & Devlet & Deneyimli $(10$ yıl) & Yok \\
Ebru & Devlet & Deneyimli $(6$ yıl) & Var (MEB'de Eğitim) \\
Gamze & Devlet & Deneyimli $(9$ yıl) & Yok \\
Ayşe & Devlet & Deneyimli $(3$ yıl) & Var (MEB'de Eğitim) \\
Zeynep & Devlet & Deneyimli $(10$ yıl) & Var (MEB'de Eğitim) \\
Ali & Özel & Deneyimsiz & Yok \\
Sevda & Özel & Deneyimsiz & Var (Üniversitede Ders) \\
Meryem & Özel & Deneyimsiz & Yok
\end{tabular}




\begin{tabular}{|c|c|c|c|}
\hline Fatma & Özel & Deneyimsiz & Var (Üniversitede Ders) \\
\hline Gizem & Özel & Deneyimsiz & Var (Üniversitede Ders) \\
\hline Nilüfer & Özel & Deneyimli (23 yıl) & Var (Seminer) \\
\hline Hatice & Özel & Deneyimli (10 y1l) & Yok \\
\hline Seçil & Özel & Deneyimli (13 yıl) & Yok \\
\hline Şeyma & Özel & Deneyimli (2 yıl) & Yok \\
\hline Burcu & Özel & Deneyimli $\quad(2$ y1l $)$ & Yok \\
\hline
\end{tabular}

Tablo 1'de görüldüğü gibi; devlet anaokulunda çalışmakta olan deneyimsiz öğretmenlerin ikisi, özel anaokulunda çalışan deneyimsiz öğretmenlerin üçü üniversitede çocuk ihmal ve istismarına yönelik bir ders aldıklarını belirtmişlerdir. Daha önce eğitim almamış bir öğretmen ise çocuk ihmali ve istismarına yönelik olarak okul öncesi öğretmenlerinin değil, daha üst kademelerdeki öğretmenlerin eğitim alması gerektiğini ifade etmiştir.

\section{Veri Toplama Araçları}

$\mathrm{Bu}$ araştırmada yarı-yapılandırılmış görüşme formu kullanılmıştır. Görüşme kişilerin deneyimleri, düşünceleri, duyguları ve davranışları hakkında detaylı bilgi edinmeye dayalı bir yöntemdir (Seggie \& Bayyurt, 2015). Bu çalışmada yeni mezun ve en az iki yıldır öğretmenlik yapan okul öncesi öğretmenlerinin çocuk ihmal ve istismarı ile çocuk haklarına yönelik görüşlerinin ve deneyimlerinin derinlemesine belirlenmesi amaçlanmıştır. Bu amaçla "Okul Öncesi Öğretmenlerin Çocuk İhmal ve İstismarı ile Çocuk Haklarına Yönelik Deneyimlerini Belirleyen Yarı Yapılandırılmış Öğretmen Görüşme Formu” kullanılmıştır.

\section{Okul Öncesi Öğretmenlerin Çocuk İhmal ve İstismarı ile Çocuk Haklarına Yönelik Görüş ve Deneyimlerini Belirleyen Yarı Yapılandırılmış Öğretmen Görüşme Formu}

Açık uçlu sorulardan oluşan yarı yapılandırılmış görüşme formu aracılığıyla çocuk ihmal ve istismarı ile çocuk haklarına yönelik görüş ve deneyimleri hakkında bilgi almak amaçlanmaktadır. Yarı-yapılandırılmış görüşme formu araştırmacılar tarafından geliştirilmiştir. Öncelikle çocuk ihmal ve istismarı ile çocuk haklarına ilişkin sorulardan oluşan bir taslak form hazırlanmıştır. Öğretmenlerin çocuk ihmal ve istismarına ilişkin görüş ve deneyimlerinin belirlenmesine yönelik hazırlanan bu taslak formda sekiz soru sorulmuştur. Taslak form çocuk hakları alanında uzman iki kişinin görüşleri alınmış ve değiştirilmeden son halini almıştır. Uzman görüşlerine göre soruların kapsam geçerliği olduğu söylenebilir. Araştırma kapsamı dışında tutulan iki okulöncesi öğretmeni ile pilot uygulama yapılmış, soruların açık ve anlaşılır olduğu görülerek form uygulamaya konmuştur. Çalışmanın ilk boyutunda ihmal ve istismarın ne olduğu ve çeşitlerine yönelik sorular yer almaktadır. İkinci boyutta ihmal ve istismar gören bir öğrencileri olup olmadığı ve varsa nasıl davranışlar gözlemledikleri belirlenmeye çalışılmıştır. Son olarak ise çocuk hakları üzerinde durulmuş, çocuk haklarına yönelik uygulamaları ele alınmış ve çocuk ihmal ve istismarı ile çocuk hakları arasında ilişki olup olmadığına yönelik görüşleri belirlenmeye çalışılmıştır. Okulöncesi öğretmenlerine yöneltilen sorular aşağıda yer almaktadır:

1. Çocuk ihmali hakkında ne düşünüyorsunuz?

2. Sınıfta ihmal edildiğini düşündüğünüz çocukların özellikleri nelerdir?

3. Çocuk istismarı hakkında ne düşünüyorsunuz?

4. Sınıfta istismar edildiğini düşündüğünüz çocukların özellikleri nelerdir?

5. Sınıfta ihmal ve istismara yönelik çocukların farkındalık kazanmaları için neler yapılabilir? 
6. Çocuk hakları hakkında ne düşünüyorsunuz?

7. Sınıfta çocuk haklarına yönelik çocukların farkındalık kazanmaları için neler yapılabilir?

8. Çocuk hakları ile çocuk ihmal ve istismarı arasındaki ilişki hakkında ne düşünüyorsunuz?

\section{Verilerin Toplanması}

Çalışmada görüşme öncesi katılımcılara, araştırmanın gerekçesine ve alana katkılarına ilişkin kısa bir açıklama yapılmış, katılımcılar araştırmaya gönüllü olarak katılmış ve hazırlanmış olan onam formunu doldurmuşlardır. Katılımcılarla yapılan görüşmeler ses kayıt cihazı ile kaydedilmiştir. Görüşmeler yaklaş1k 35 dakika sürmüştür. Görüşme sonunda görüşler okunarak teyit alınmış ve eklemek istedikleri bir şey olup olmadığı sorulmuştur. Böylece, görüşmede elde edilen verilerin inandırıcılığ (iç geçerliliği) artırılmıştır.

\section{Verilerin Analizi}

Verilerin analizinde içerik analizi kullanılmıştır. İçerik analizinde amaç, benzeyen noktaları temalar halinde ve kodlar şeklinde sınıflandırılarak açıklamak ve tema ve kodlar arasındaki bağlantıları tanımlayarak değerlendirmektir (Yıldırım ve Şimşek, 2011). İki araştırmacı tarafından görüşme verileri ayrı ayrı analiz edilerek, kategoriler ve bu kategoriler altında açıklanabilen kodlar belirlenmiştir. Daha sonra üç araştırmacı bir araya gelmiş ve yapılan analizleri değerlendirmiştir. Görüş birliğine varılamayan noktalar tartışılmış ve uzlaşma sağlanmıştır. Araştırmacıların görüş birliği ve görüş ayrılı̆̆ı noktalarında Miles ve Huberman'ın (1994) formülü ile hesaplama yapılmıştır. Her bir veri kaynağından ortaya çıkan tema ve kategoriler oluşturulmuştur. Kodlayıcılar arasındaki görüş birliği .72. olarak hesaplanmıştır. Ayrıca katılımcıların görüşlerinden alıntılar yapılarak, bire bir aktarım da yapılmıştır.

\section{Bulgular}

Öğretmenlerin ihmale yönelik görüşleri Tablo 2'de verilmiştir.

Tablo 2: Öğretmenlerin İhmale Yönelik Görüşleri

\begin{tabular}{|c|c|c|c|c|c|c|}
\hline \multirow[b]{3}{*}{ Temalar } & \multirow[b]{3}{*}{ Kategoriler } & \multirow[b]{3}{*}{ Kategorilere İlişkin Örnek İfadeler } & \multicolumn{4}{|c|}{ Toplam } \\
\hline & & & \multicolumn{2}{|c|}{ Devlet } & \multicolumn{2}{|c|}{ Özel } \\
\hline & & & 完 & 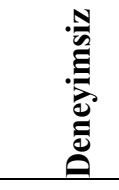 & 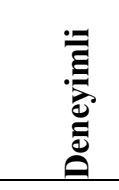 & 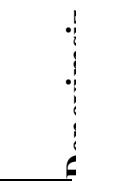 \\
\hline & $\begin{array}{l}\text { İlgi } \\
\text { göstermeme }\end{array}$ & $\begin{array}{l}\text { Ailenin ilgisizliği, çocuğu yok saymak, göz } \\
\text { göre göre kulak arkası yapmak, } \\
\text { ihtiyaçlarını algılayamamak, çocuğa } \\
\text { yapılmayan- anlatılmayan herşey, çocuğun } \\
\text { unutulması, çocuğun kendini ifade } \\
\text { edememesi. }\end{array}$ & $\begin{array}{l}\text { Gamze(2) } \\
\text { Ebru } \\
\text { Esra } \\
\text { Zeynep } \\
\text { Ayşe }\end{array}$ & $\begin{array}{l}\text { Esma } \\
\text { Filiz }\end{array}$ & $\begin{array}{l}\text { Nilüfer } \\
\text { Seçil }\end{array}$ & $\begin{array}{l}\text { Fatma } \\
\text { Ali } \\
\text { Gizem }\end{array}$ \\
\hline Tanım & $\begin{array}{l}\text { Sorumluluğu } \\
\text { nu yerine } \\
\text { getirmeme }\end{array}$ & $\begin{array}{l}\text { Ailenin üzerine düşeni yapmaması, annenin } \\
\text { hayatını düzene koymaması, giyinme, } \\
\text { bakım, sağlık vb. her yönden aksatılması, } \\
\text { tedbirsizlik, duygusal/sosyal /ekonomik } \\
\text { yönden haklarının çocuğa verilmemesi, } \\
\text { çocuğa doğruyu yanlışı anlatmamak, } \\
\text { çocuğun belli bir konuda eksik bırakılması }\end{array}$ & Zeynep(2) & $\begin{array}{l}\text { Esma(2 } \\
\text { Hülya }\end{array}$ & $\begin{array}{l}\text { Hatice } \\
\text { Seçil } \\
\text { Burcu }\end{array}$ & Gizem \\
\hline
\end{tabular}




\begin{tabular}{|c|c|c|c|c|c|c|}
\hline \multirow[b]{4}{*}{ Toplam } & $\begin{array}{l}\text { Sevgi } \\
\text { göstermeme }\end{array}$ & $\begin{array}{l}\text { Çocuğun sevgi görmemesi, çocuğu sevgisiz } \\
\text { bırakma, çocuğu bakım ve sevgi anlamında } \\
\text { eksik bırakmak }\end{array}$ & $\begin{array}{l}\text { Esra } \\
\text { Ayşe }\end{array}$ & & & Sevda \\
\hline & $\begin{array}{l}\text { Mahrum } \\
\text { birakma }\end{array}$ & $\begin{array}{l}\text { Kişinin var olan haklarından mahrum } \\
\text { bırakılması, Özerkliğini kısıtlamak, çocuğun } \\
\text { yaşamında gerekli olan ve olacak şeylerden } \\
\text { çocuğu mahrum etmek }\end{array}$ & & $\begin{array}{l}\text { Melike } \\
(2)\end{array}$ & & Ali \\
\hline & $\begin{array}{l}\text { İstenmeden } \\
\text { Yapılanlar }\end{array}$ & $\begin{array}{l}\text { Önlenemeyen şeyler, düşüncesizce yapılan } \\
\text { hareketler }\end{array}$ & Zeynep & & Şeyma & \\
\hline & & & 11 & 7 & 6 & 6 \\
\hline \multirow{5}{*}{ Çeşitleri } & $\begin{array}{l}\text { Duygusal } \\
\text { İhmal }\end{array}$ & $\begin{array}{l}\text { Çocuğa ceza vermek, ailenin çocuğun } \\
\text { duygusal değişimlerini fark etmemesi, evde } \\
\text { çocuğa sevgi ve ilgi göstermemek, çocuğun } \\
\text { sorularını cevaplamadan geçiştirmek, sen } \\
\text { bunu yapamazsın demek, aşağılamak, } \\
\text { arkadaşlarının dışlaması, çocuğu oyalamak } \\
\text { için eline tablet vermek, ailenin çocuğa } \\
\text { zaman ayırmaması }\end{array}$ & $\begin{array}{l}\text { Zeynep } \\
\text { Ebru Esra }\end{array}$ & $\begin{array}{l}\text { Esma } \\
\text { Meryem }\end{array}$ & Burcu & $\begin{array}{l}\text { Fatma } \\
\text { Sevda } \\
\text { Gizem } \\
\text { Ali } \\
\text { Meryem }\end{array}$ \\
\hline & $\begin{array}{l}\text { Fiziksel } \\
\text { İhmal }\end{array}$ & $\begin{array}{l}\text { Çocuğun yeterince beslenmemesi, çocuğun } \\
\text { bakımını yapmamak, öz-bakım becerilerinin } \\
\text { tamamlanmaması, çocuğun pis olması, } \\
\text { balkon korkuluğunun olmaması }\end{array}$ & $\begin{array}{l}\text { Gamze } \\
\text { Esra }\end{array}$ & Hülya & & $\begin{array}{l}\text { Meryem } \\
\text { Gizem } \\
\text { Fatma } \\
\text { Ali }\end{array}$ \\
\hline & $\begin{array}{l}\text { Eğitimsel } \\
\text { İhmal }\end{array}$ & $\begin{array}{l}\text { Okula başlamış çocuğu desteklememek, } \\
\text { Suriyeli çocukların yaşadığı zorluklar, } \\
\text { çocuğa eğitim aldırmamak, özel } \\
\text { gereksinimli çocuklara gereken eğitimi } \\
\text { aldırmamak, }\end{array}$ & Zeynep & $\begin{array}{l}\text { Filiz } \\
\text { Esma }\end{array}$ & Nilüfer & Meryem \\
\hline & Sosyal İhmal & $\begin{array}{l}\text { Çocuğun arkadaşları ile görüşmesine izin } \\
\text { vermemek }\end{array}$ & & & & Ali \\
\hline & $\begin{array}{l}\text { Ekonomik } \\
\text { İhmal }\end{array}$ & Harçlığını kesmek & & & & Fatma \\
\hline Toplam & & & 6 & 5 & 3 & 12 \\
\hline
\end{tabular}

Tablo 2'de de görüldüğü gibi okul öncesi öğretmenlerinin çocuk ihmali hakkında düşünceleri tanım ve çeşitleri alt temalarında toplanmıştır. Öğretmenlerin ihmalin tanımı ile ilgili görüşleri; sorumluluğunu yerine getirmeme, sevgi göstermeme, ilgi göstermeme, istenmeden yapılanlar ve mahrum bırakma alt temalarına ayrılmıştır. Sorumluluğunu yerine getirmeme alt temasında devlette çalışan deneyimli öğretmenler iki, deneyimsiz öğretmenler üç görüş bildirirken, özelde çalışan deneyimli öğretmenler üç, deneyimsiz öğretmenler bir görüş bildirmişlerdir. Sevgi göstermeme alt temasında ise özel ve devlette çalışan öğretmenlerin görüşleri incelendiğinde; devlette çalışan deneyimli öğretmenler iki, özelde çalışan deneyimsiz öğretmenler bir görüş bildirmiştir. Özelde çalışmakta olan deneyimli öğretmenler ve devlette çalı̧̧an deneyimsiz öğretmenlerin görüş bildirmediği belirlenmiştir. İlgi göstermeme alt temasında devlette çalışan deneyimli öğretmenler altı, deneyimsiz öğretmenler iki görüş bildirirken, özelde çalışmakta olan deneyimli öğretmenler iki, deneyimsiz öğretmenler üç görüş bildirmişlerdir. İstenmeden yapılanlar alt temasında ise özel ve devlette çalışan öğretmenlerin görüşleri incelendiğinde; devlette ve özelde çalışan deneyimli öğretmenler bir görüş bildirirken, devlette çalışan deneyimsiz öğretmenler ve özelde çalışan deneyimsiz öğretmenlerin görüş bildirmediği belirlenmiştir. Mahrum bırakma alt temasında ise devlette çalışan deneyimsiz öğretmenler iki, özelde çalışan deneyimsiz öğretmenler bir görüş 
bildirmiştir. Görüşmeler sonucunda öğretmenlerin bu alt temalardan sevgi göstermeme, ilgi göstermeme ve mahrum bırakma üzerinde daha çok durdukları belirlenmiştir. Ayrıca ihmalin tanımında öğretmenler genellikle sevgi, ilgi, sorumluluk ve aksatılma gibi kelimeler üzerine yoğunlaşmışlardır. Öğretmenlerin ihmalin tanımına yönelik görüşleri aşağıda verilmiştir:

İhmal kesinlikle aile ile ilgili. İhmalin \%80'i ailenin çocuğa göstermediği ilgi, üstlenmediği sorumluluktur. Mesela bir çocuk bir davranış karşısında yaşadı̆̆ küçük bir şeyden dolayı kırılmış olabilir. Ailenin çocuktaki duygusal değişimleri fark etmesi gerekir. Fark etmediği zaman çocuk aile ile olan bağını yavaş yavaş kopartmaya başlıyor (Esma). olur (Sevda).

Acıktığında yemeğini vermez ya da abur cuburla geçiştirir. Böylece beslenmesini ihmal etmiş

Okulda mesela sınıfta arkadaşları ile dışlanması çocuğun, öğretmenin bunu gözden kaçırıp hani bu duruma müdahale etmemesi hepsi bunların ihmal örneği(Zeynep). (Ebru).

Var olan bir grup içerisinde onu görmemek ya da onun ona özgü olan şeyleri fark etmemek

İhmalin çeşitleri ise duygusal, fiziksel, sosyal, ekonomik ve eğitimsel ihmal alt temaları altında toplanmıştır. Fiziksel ihmal alt temasında devlette çalışan deneyimli öğretmenler iki, deneyimsiz öğretmenler 1 görüş bildirirken, özelde çalışmakta olan deneyimsiz öğretmenler dört görüş bildirmiştir. Duygusal ihmal alt temasında ise özel ve devlette çalışan öğretmenlerin görüşleri incelendiğinde; devlette çalışan deneyimli öğretmenler üç, deneyimsiz öğretmenler iki görüş bildirirken, özelde çalışmakta olan deneyimli öğretmenlerin iki, deneyimsiz öğretmenlerin beş görüş bildirdikleri belirlenmiştir. Sosyal ihmal alt temasında sadece özelde çalışan öğretmenler bir görüş bildirmiştir. Ekonomik ihmal alt temasında ise özel ve devlette çalışan öğretmenlerin görüşleri incelendiğinde; sadece özelde çalışan deneyimsiz öğretmenler bir görüş bildirmiştir. Eğitimsel ihmal alt temasında devlette ve özelde çalışan öğretmenlerin görüşleri incelendiğinde; devlette çalışan deneyimli öğretmenler bir, deneyimsiz öğretmenler iki görüş bildirirken, özelde çalışmakta olan deneyimli öğretmenler bir, deneyimsiz öğretmenler bir görüş bildirmişlerdir. Öğretmenler ihmalin çeşitlerini aşağıdaki örneklerle betimlemişlerdir:

Evde anne babasina sarllp anne baba sevgisi alamiyorsa bu duygusal olarak ihmal edildiğini gösterir. Bu ihmali de başka şekilde başka yerlerden karşılayabiliyor bazı çocuklar.(Melike)

Daha çok ailelerden kaynaklanan bir ihmal oluyor. Çocukları sırf oyalansın diye özellikle şu telefonlar tabletler denilen şeylerle oyalamak için ellerine veriyorlar ve çocukla olan ilgilerini alakalarını kesiyorlar aslında.(Nilüfer)

İhmalin çeşitleri mesela bir çocuğa sevgini göstermezsin ya da onunla ilgilenmezsin, sosyal yönden onu desteklemezsin bu da bir ihmaldir. (Ali) 
Tablo 3: İhmal Edilen Çocuğun Özelliklerine İlişskin Öğretmenlerin Görüşleri

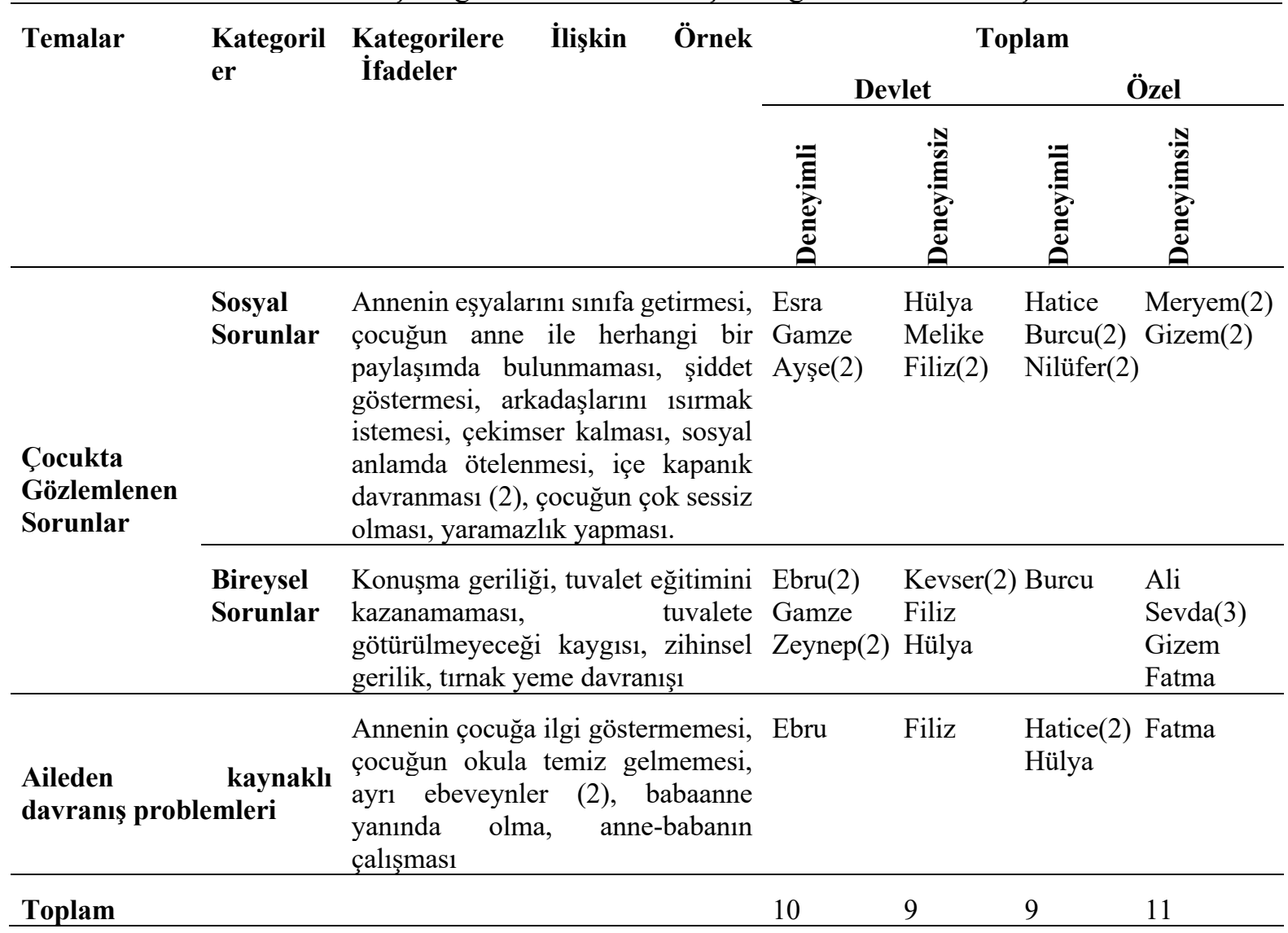

Tablo 3'te görüldüğü gibi; öğretmenler ihmal edilen çocukların davranışlarına yönelik olarak 39 farklı görüş bildirmiştir. Öğretmenlerin görüşlerine göre ihmal edildiği düşünülen çocukta davranışlar, çocukta gözlemlenen davranışlar ve aileden kaynaklı davranış problemleri olarak iki temaya ayrılmıştır. Çocukta gözlemlenen davranışlar teması ise bireysel davranış problemleri (16) ve sosyal davranış problemleri (17) olarak iki alt temaya ayrılmıştır. Bireysel davranış problemleri alt temasına ilişkin olarak devlette ve özelde çalışan öğretmenlerin görüşleri incelendiğinde; devlette çalışan deneyimli öğretmenlerin beş, deneyimsiz öğretmenlerin dört görüş bildirdikleri, özelde çalışmakta olan deneyimli öğretmenlerin bir, deneyimsiz öğretmenlerin altı görüş bildirdikleri belirlenmiştir. Sosyal davranış problemleri incelendiğinde ise devlette çalışan deneyimli öğretmenler dört, deneyimsiz öğretmenler dört görüş bildirirken, özelde çalışmakta olan deneyimli öğretmenlerin beş, deneyimsiz öğretmenlerin dört görüş bildirdikleri belirlenmiştir. Aileden kaynaklı davranış problemleri teması öğretmen görüşlerine göre incelendiğinde; devlette çalışan deneyimli öğretmenler bir, deneyimsiz öğretmenler bir görüş bildirirken, özelde çalışan deneyimli öğretmenler üç, deneyimsiz öğretmenlerin bir görüş bildirmişlerdir.

Bireysel davranış problemlerinde çocuğun kendisiyle ilgili gelişimindeki olumsuzluklar verilirken sosyal davranış problemlerinde daha çok etrafına karşı sergilediği davranış problemlerinden bahsedilmiştir. Genel anlamda ailenin çocukların ihtiyaçlarının farkında olmadıkları, gerekli ilgiyi gösterip takibi sağlamadıkları üzerinde durulduğu görülmektedir. Davranış problemlerine ilişkin örnekler aşağıda verilmiştir:

Özel eğitime gereksinim duyan çocuklarda karşılaşlyoruz bu tarz konularla. O da çok ihmal değil aslında birazcık velinin eğitimsizliği oluyor. Yani birkaç tane öyle olmuştu onlarda özel eğitime ihtiyaç duyan çocuklardı diyeyim normal gelişim gösteren çocuklarda hiç görmedim (Zeynep). 
Fiziksel olarak ihmal edildiğini düşündüğüm bir çocuğum var. Çocuk okula pis geliyor. Çok fazla meşgul olduklarını düşünüyorum çünkü bazen almaya bile komşusu geliyor(Meryem).

...Daha fazla kendini kabul ettirmeye çalışıyor sınıfta. Bu davranışı yapamadiğında, kendini kabul ettiremediğinde şiddete başvuruyor (Esra).

Şu an bizim sınıfimızda var hatta çok ihmal edilmiş. Annesi babası çalışıyormuş. Galiba anneannesine bırakmışlar. Kadın sürekli televizyon izletmiş çocuğa. Çocuk konuşmakta bile zorlaniyormuş, daha önceki süreçte...(Ali).

Tablo 4: Öğretmenlerin İstismarına İlişkin Görüşleri

\begin{tabular}{|c|c|c|c|c|c|c|}
\hline \multirow[t]{3}{*}{ Temalar } & \multirow[t]{3}{*}{ Kategoriler } & \multirow[t]{3}{*}{ Kategorilere İlişkin Örnek İfadeler } & \multicolumn{4}{|c|}{ Toplam } \\
\hline & & & \multicolumn{2}{|c|}{ Devlet } & \multicolumn{2}{|r|}{ Özel } \\
\hline & & & 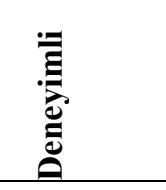 & . & & . \\
\hline \multirow{4}{*}{ Tanım } & $\begin{array}{l}\text { Güç } \\
\text { Kullanmak }\end{array}$ & $\begin{array}{l}\text { Hırpalamak, azarlamak, iteklemek, } \\
\text { tecavüz, alıkoymak, engellemek, } \\
\text { hakkını elinden almak, cezai } \\
\text { yaptırımlarda bulunmak }\end{array}$ & $\begin{array}{l}\text { Zeynep(2) } \\
\text { Ayşe(2) }\end{array}$ & $\operatorname{Esma}(3)$ & Şeyma & $\begin{array}{l}\text { Ali } \\
\text { Meryem(3) }\end{array}$ \\
\hline & $\begin{array}{l}\text { Duygusal } \\
\text { Baskı }\end{array}$ & $\begin{array}{l}\text { Çocuğu hor görmek, yalnız } \\
\text { bırakmak, azarlamak, çocuğu } \\
\text { aşağılamak, çocukların duyguları ile } \\
\text { oynamak, bir insanın duygularını } \\
\text { kullanmak }\end{array}$ & Esra & Esma & Hatice & $\begin{array}{l}\text { Fatma(2) } \\
\text { Ali }\end{array}$ \\
\hline & Zarar Vermek & $\begin{array}{l}\text { Çocuğun gelişim alanlarına zarar } \\
\text { vermek, çocuğun belli bir konuda } \\
\text { zarara uğratılması, bir şeye maruz } \\
\text { bırakmak, kasten birinin bilerek } \\
\text { isteyerek zarar vermesi }\end{array}$ & Ayşe & $\begin{array}{l}\text { Filiz(2) } \\
\text { Melike }\end{array}$ & & Ali \\
\hline & Faydalanmak & $\begin{array}{l}\text { Kendi zevkleri için kullanılması, } \\
\text { çocuktan faydalanma/yarar sağlama, } \\
\text { bireyin özgürlük alanına izinsiz bir } \\
\text { şekilde girilmesi, tamamen bilinçli } \\
\text { olarak yapmak, faydalanmaya } \\
\text { yönelmek }\end{array}$ & $\begin{array}{l}\text { Ebru } \\
\text { Gamze }\end{array}$ & $\begin{array}{l}\text { Kevser } \\
\text { Esma }\end{array}$ & Hatice & \\
\hline Toplam & & & 8 & 9 & 3 & 8 \\
\hline \multirow{2}{*}{ Çeşitleri } & $\begin{array}{l}\text { Fiziksel } \\
\text { İstismar }\end{array}$ & $\begin{array}{l}\text { Çocuğun şiddete maruz kalması, } \\
\text { çocuğun vücudundaki morarmalar, } \\
\text { aileler tarafından uygulanan şiddet, } \\
\text { Çocuğun dövülmesi, çocukları itip, } \\
\text { kakmak, sosyo-kültürel düzeyi düşük } \\
\text { ailelerde fiziksel şiddet }\end{array}$ & Esra & $\begin{array}{l}\text { Filiz } \\
\text { Melike }\end{array}$ & Burcu & $\begin{array}{l}\text { Meryem } \\
\text { Sevda }\end{array}$ \\
\hline & $\begin{array}{l}\text { Duygusal } \\
\text { İstismar }\end{array}$ & $\begin{array}{l}\text { Çocuğun kendini rahatsı ve } \\
\text { güvensiz hissetmesi, bireye baskı } \\
\text { kurulması, çocuğun ağır hakaretlere } \\
\text { maruz kalması, çocuğu görmezden } \\
\text { gelmek, çocuğu başından } \\
\text { atmak/reddetmek }\end{array}$ & Esra & $\begin{array}{l}\text { Filiz } \\
\text { Kevser } \\
\text { Hülya }\end{array}$ & Hatice & \\
\hline
\end{tabular}




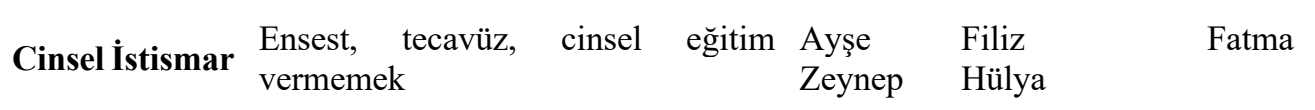

Toplam

$\begin{array}{llll}4 & 7 & 2 & 3\end{array}$

Tablo 4'te istismarın tanımı ve çeşitleri hakkında öğretmen görüşleri gösterilmiştir. İstismarın tanımı güç kullanmak, zarar vermek, faydalanmak ve duygusal baskı ifadeleri altında ele alınmıştır. Öğretmenler genellikle güç kullanmak ve faydalanmak üzerine yorumlar yaparak istismarı tanımlamışlardır. Alt temalar kapsamında öğretmenler toplam 26 görüş bildirmişlerdir. Güç kullanmak alt temasına yönelik, devlette ve özelde çalışan öğretmenlerin görüşleri incelendiğinde; devlette çalışan deneyimli öğretmenler 4, deneyimsiz öğretmenler 3 görüş bildirirken, özelde çalışan deneyimli öğretmenler 1, deneyimsiz öğretmenler 4 görüş bildirmiştir. Faydalanmak alt temasında ise devlette çalışan deneyimli öğretmenler 2, deneyimsiz öğretmenler 2 görüss bildirirken, özelde çalışan deneyimli öğretmenler 1 görüş bildirmiştir. Zarar vermek alt temasına ilişkin olarak devlette ve özelde çalışan öğretmenlerin görüşleri incelendiğinde; devlette çalışan deneyimli öğretmenler 1 , deneyimsiz öğretmenler 3 görüş bildirirken, özelde çalışmakta olan deneyimsiz öğretmenler 1 görüş bildirmiştir. Duygusal baskı alt teması incelendiğinde; devlette çalışan deneyimli öğretmenler 1, deneyimsiz öğretmenler 1 görüş bildirirken, özelde çalışmakta olan deneyimli öğretmenler 1 , deneyimsiz öğretmenler 3 görüş bildirmişlerdir. Öğretmenlerin istismarın tanımına yönelik görüşleri aşağıda verilmiştir:

Çocuğu ekonomik, duygusal, cinsel yönlerden hor görmek, yalnız bırakmak (Fatma).

İstismar etmek; hakkını elinden almak, alıkoymak, engellemek gibi (Meryem).

Hep cinsellik olarak geliyor aklıma şu an günümüzde ve küçük yaş grubunda karşılaştığımız için. Tamamen aslında sadece o boyutta değil. Küçük yaşta bir çocuğun çalıştırllması ve onun üzerinden para kazanma çabası da bir istismara giriyor (Ebru).

Tablo 4'te belirtildiği gibi istismarın çeşitleri fiziksel, duygusal ve cinsel istismar olarak üç alt temaya ayrılmıştır. Öğretmenler istismar çeşitleri üzerine fiziksel, duygusal ve cinsel istismar haricinde de ekonomik, sosyal, psikolojik ve madde bağımlılı̆̆ gibi cevaplar vermişlerdir. Öğretmenlerin görüşlerine göre en belirgin fark ettikleri istismar çeşidi fiziksel istismardır ve en az anlaşılan ise duygusal istismar olmaktadır. Fiziksel istismar alt teması devlette ve özelde çalışan öğretmenlerin görüşleri incelendiğinde; devlette çalışan deneyimli öğretmenler 1 , deneyimsiz öğretmenler 2 görüş bildirirken, özelde çalışmakta olan deneyimli öğretmenler 1 , deneyimsiz öğretmenler 2 görüş bildirmiştir. Duygusal istismar alt temasına göre; devlette çalışan deneyimli öğretmenler 1, deneyimsiz öğretmenler 3 görüş bildirirken, özelde çalışmakta olan deneyimli öğretmenler 1 görüş bildirmiştir. Cinsel istismar alt teması devlette ve özelde çalışan öğretmenlerin görüşleri incelendiğinde; devlette çalışan deneyimli öğretmenler 2, deneyimsiz öğretmenler 2 görüş bildirirken, özelde çalışmakta olan deneyimsiz öğretmenler 1 görüş bildirmiştir. Öğretmenlerin istismarın çeşitlerine ilişkin görüşleri aşağıda verilmiştir:

En fazla da duygusal oluyor bu ortaya kolay çıkmıyor, anlaşılması zor. En belirgin gözlemlediğimiz fiziksel, tecavüzü de söylerlerse (Hülya).

Mesela fiziksel açıdan eğer dövülüyorsa çocuk şiddet görüyorsa fiziksel açıdan ya da ağır hakaretlere maruz kalıyorsa duygusal açıdan istismar(Filiz).

Günümüzde şu an en önemlisi cinsel istismar Çocukların üzerinde. Keşke bunu söylemekten bu konuyu tartışmaktan utanır olsaydık. En önemlisi şu anda o. Bence iyi takip edilmeli(Nilüfer).

İstismar çocukların sadece çocukların da değil bireyin özgürlügünü, özgürlük alanına girilmesidir. İzinsiz bir şekilde girilmesidir. Cinsel istismar olabilir, sözsel olabilir o şekilde(Kevser). 
Tablo 5: İstismara Uğradığı Düşünülen Çocuğun Davranışları

\begin{tabular}{|c|c|c|c|c|c|c|}
\hline \multirow[t]{3}{*}{ Temalar } & \multirow[t]{3}{*}{ Kategoriler } & \multirow[t]{3}{*}{ Kategorilere İlişkin Örnek İfadeler } & \multicolumn{4}{|c|}{ Toplam } \\
\hline & & & \multicolumn{2}{|c|}{ Devlet } & \multicolumn{2}{|c|}{ Özel } \\
\hline & & & 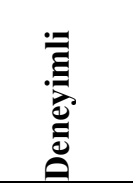 & 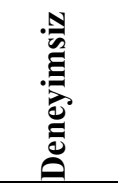 & 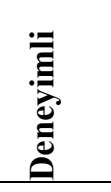 & 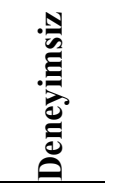 \\
\hline \multirow[t]{2}{*}{$\begin{array}{l}\text { Davranış } \\
\text { Problemleri }\end{array}$} & $\begin{array}{l}\text { İçselleştirme } \\
\text { Davranış } \\
\text { Problemleri }\end{array}$ & $\begin{array}{l}\text { Konuşma geriliği, içe kapanıklık, } \\
\text { komutları dinlememe, aksi tavırlar, } \\
\text { fevri davranışlar, cezalandırılma } \\
\text { korkusu, kendini kabul ettirmeye } \\
\text { çalışması, kimse ile konuşmama, } \\
\text { kendini suçlama, çekingen ve ürkek, } \\
\text { gözlerini kaçırma }\end{array}$ & $\begin{array}{l}\text { Zeynep } \\
\text { Ebru(3) } \\
\text { Esra(2) }\end{array}$ & Esma(3 & Nilüfer & $\begin{array}{l}\text { Ali(3) } \\
\text { Sevda }\end{array}$ \\
\hline & $\begin{array}{l}\text { Dışsallaştırma } \\
\text { Davranış } \\
\text { Problemleri } \\
\end{array}$ & $\begin{array}{l}\text { Şiddet yanlısı, dokunma, vurma, yere } \\
\text { tükürme, yüzünde morluk, küfür ve } \\
\text { argo sözcük kullanmak }\end{array}$ & $\begin{array}{l}\text { Esra } \\
\text { Gamze }\end{array}$ & $\begin{array}{l}\text { Esma } \\
(2) \\
\text { Hülya }\end{array}$ & & $\begin{array}{l}\text { Gizem } \\
\text { Meryem } \\
\text { Fatma } \\
\end{array}$ \\
\hline Toplam & & & 8 & 6 & 1 & 7 \\
\hline
\end{tabular}

Tablo 5'te görüldüğü gibi; çalışmaya katılan öğretmenlerin istismara uğradığını düşündükleri çocuklara yönelik gözlemledikleri davranışlara dair toplamda 22 görüşün olduğu belirlenmiş ve görüssler içselleştirme ve dışsallaştırma davranış problemleri olarak iki alt temaya ayrılmıştır. Dışsallaştırma davranış problemleri alt teması devlette ve özelde çalışan öğretmenlerin görüşlerine göre incelendiğinde; devlette çalışan deneyimli öğretmenler 2, deneyimsiz öğretmenler 3 görüş bildirirken, özelde çalışmakta olan deneyimsiz öğretmenler 3 görüş bildirmiştir. İçselleştirme davranış problemleri alt temasında ise devlette çalışan deneyimli öğretmenler 6 , deneyimsiz öğretmenler 3 görüş bildirirken, özelde çalışmakta olan deneyimli öğretmenler 1, deneyimsiz öğretmenler 4 görüş bildirmiştir.

Çocuklarda gözlenen içselleştirme davranış problemleri konuşma geriliği, içe kapanıklık, komutları dinlememe, gözlerini kaçırma olarak ifade edilirken, dışsallaştırma davranış problemleri daha çok çocukların gösterdiği şiddet içerikli davranışlar ve çocuğun yüzünde görülen morluklar olarak ifade edilmiştir. İstismara maruz kalan çocuklarda küfür ve argo sözcük kullanımı gibi davranış problemlerinin de ortaya çıktığı öğretmenler tarafından belirtilmiştir.

Yüzünde birkaç kere morluk gördüm. Sorduğumda düştü dediler ama düşünce olacak şeyler gibi değildi. Özel bir okulda çalışıyorum ama karşılaştım. Dokunmadan konuşmayı bilmiyor çocuk. Bir şey anlatacă̆ı zaman ya ayağıyla vuruyor, ya eliyle tutuyor, dikkat çekip sonra konuşmak istiyor (Gizem).

... Fiziksel olarak da duygusal olarak da çok fazla istismar ediliyor. Özellikle fiziksel olarak istismara uğrayan çocuklar daha çekingen daha ürkek oluyorlar. Başına okşamaya kalktığınızda bile çocukta bir tepki oluşuyor. Bu şekilde anlayabiliyorum onları (Esra).

Bir gün etkinlik sirasında kolunda morluklar olduğunu farkettim ve ona bunun sebebini sordum. Tedirgin ve kaçamak cevaplar verdi. Durumu yönetime de bildirdim, üzerine çalışmaya başladık. Serbest zaman etkinliğinde ailesini çizmesini istediğimde gerçeği öğrendik. Öğrenci annesinin elinde merdane, babasının elinde terlik çizmişti. Anlamını soruduğumda açıldı ve o anda 
kriz geçirdi. Aynı zamanda çocukta epilepsi varmış. Sonrasında sakinleştirdik ve durumu rehberlik ögretmeniyle görüşmüştük (Meryem).

Tablo 6: Öğretmenlerin İhmal ve İstimara İlişkin Olarak Uyguladıkları Etkinlikler

\begin{tabular}{|c|c|c|c|c|c|c|}
\hline \multirow[b]{3}{*}{ Tema } & \multirow[b]{3}{*}{ Kategoriler } & \multirow[b]{3}{*}{$\begin{array}{l}\text { Kategorilere } \\
\text { İfadeler }\end{array}$} & \multicolumn{4}{|l|}{ Toplam } \\
\hline & & & \multirow{2}{*}{$\begin{array}{c}\text { Devlet } \\
\text { 局 } \\
\text { 离 } \\
\end{array}$} & \multicolumn{3}{|c|}{ Özel } \\
\hline & & & & 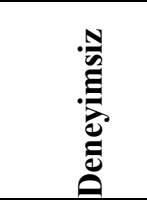 & 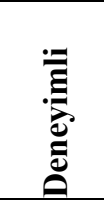 & 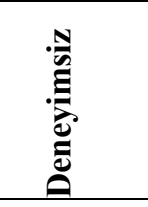 \\
\hline \multirow{3}{*}{ Etkinlik } & $\begin{array}{l}\text { Cinsel } \\
\text { Farkindalığa } \\
\text { Yönelik } \\
\text { Etkinlikler }\end{array}$ & $\begin{array}{l}\text { Kısa sohbetler, sanat etkinliği, } \\
\text { özel alan etkinliği, özel bölgelerin } \\
\text { anlatımı, çığlık atmayı öğretmek, } \\
\text { beden farkındalığı, mahremiyet } \\
\text { eğitimi, özel bölgeleri konusunda } \\
\text { sözel olarak uyarma }\end{array}$ & $\begin{array}{l}\text { Zeynep(2) } \\
\text { Gamze } \\
\text { Ebru } \\
\text { Esra }\end{array}$ & $\begin{array}{l}\text { Filiz } \\
\text { Hülya }\end{array}$ & $\begin{array}{l}\text { Şeyma } \\
\text { Seçil }\end{array}$ & $\begin{array}{l}\text { a Sevda } \\
\text { Meryem } \\
\text { Fatma } \\
\text { Gizem(2) }\end{array}$ \\
\hline & $\begin{array}{l}\text { Sosyal } \\
\text { Farkındalığa } \\
\text { Yönelik } \\
\text { Etkinlikler }\end{array}$ & $\begin{array}{l}\text { Drama, firsat eğitimi, birbirimize } \\
\text { nasıl davranmalıyız etkinliği, nasıl } \\
\text { saygilı olabiliriz etkinliği, hikaye } \\
\text { etkinliği, kitap okuma, video. }\end{array}$ & Ayșe & $\begin{array}{l}\text { Esma(4) } \\
\text { Hülya(2) }\end{array}$ & Burcu & $\begin{array}{l}\text { Sevda } \\
\text { Fatma }\end{array}$ \\
\hline & $\begin{array}{l}\text { Çocuk Haklarına } \\
\text { Yönelik } \\
\text { Etkinlikler }\end{array}$ & $\begin{array}{l}\text { Hakları olduğunu/birey } \\
\text { olduklarını vurgulama, her } \\
\text { etkinlikte söz hakkı, haklarının } \\
\text { olduğunu söyleyip sorumluluk } \\
\text { vermek, kitap okuma, Video }\end{array}$ & $\begin{array}{l}\text { Esra(2) } \\
\text { Ebru }\end{array}$ & Hülya & Burcu & Fatma \\
\hline Toplam & & & 9 & 9 & 4 & 8 \\
\hline
\end{tabular}

Tablo 6' da görüldüğü gibi öğretmenler ihmal ve istismara yönelik uyguladıkları etkinliklere ilişkin toplamda 30 görüş bildirmişlerdir. Öğretmenlerin ihmal ve istismara yönelik yaptıkları etkinlikler; cinsel farkındalığa yönelik etkinlikler, bireysel farkındalığa yönelik etkinlikler ve sosyal farkındalığa yönelik etkinlikler olarak üç alt temaya ayrılmıştır. Cinsel farkındalığa yönelik etkinlikler alt temasında devlette çalışan deneyimli öğretmenler 5, deneyimsiz öğretmenler 2 görüş bildirirken, özelde çalışan deneyimli öğretmenler 2, deneyimsiz öğretmenler 5 görüş bildirmişlerdir. Çocuk haklarına yönelik etkinlikler alt temasındaki görüşler incelendiğinde ise; devlette çalışmakta olan deneyimli öğretmenler 3, deneyimsiz öğretmenler 1 görüş, özelde çalışan deneyimli öğretmenler 1 , deneyimsiz öğretmenler de 1 görüş bildirmişlerdir. Sosyal farkındalığa yönelik etkinlikler alt temasında devlette çalışan deneyimli öğretmenlerin 1, deneyimsiz öğretmenlerin 6 görüş, özelde çalışan deneyimli öğretmenlerin 1, deneyimsiz öğretmenlerin 2 görüş bildirdiği belirlenmiştir.

Tablo 6 incelendiğinde öğretmenlerin ihmal ve istismara ilişkin etkinliklerde daha çok cinsel farkındalığa yönelik etkinlikler düzenlemekte oldukları görülmektedir. Cinsel istismarın çok fazla gündemde olması öğretmenlerin çocuklara bu konuda farkındalık kazandırmak istemesine sebep olmuş olabilir. Cinsel farkındalığa yönelik etkinliklerin çocukların özel bölgelerini tanımaları ve mahremiyet eğitimi üzerine yoğunlaşmış durumda olduğu görülmektedir. Öğretmenler çocukların haklarının ve sorumluluklarının bilincinde olduğunda istismar ve ihmale karşı korumasız kalmayacaklarını düşünmektedirler. Bu sebeple çocuk haklarına yönelik etkinliklere sınıflarında yer vermektedirler. Hak kavramının bilincinde olan çocukların herhangi bir istismar ya da ihmale uğradığında bunu ailesi ve öğretmenleri ile paylaşmak konusunda kendini daha rahat hissedeceği düşünülmektedir. Akranlar arasında da ihmale rastlayan öğretmenler bu alanda sosyal farkındalığı arttırıcı etkinliklere yer vermektedir. Sayg1 gibi temel kavramlar üzerinde durulmaktadır. Çocuk 
haklarına ve sosyal farkındalığa yönelik olarak öğretmenlerin kitap okuma, video izletme ve hikaye etkinliklerinden yararlandıkları belirlenmiştir. Öğretmenlerin 4'ü sosyal farkındalığa yönelik olarak, 2'si çocuk haklarına yönelik olarak bu etkinlikleri uygulamışlardır. Öğretmenlerin ihmal ve istismara ilişkin uyguladıkları etkinliklere yönelik görüşlerinden alıntılar aşağıda belirtilmiştir:

Uygulamalı bir şekilde vücutlarının özel bölgeleri olduğunu onlar izin vermeden kimsenin dokunamayacağını vurgulamaya çalışıyoruz. Bu da gerçekten etkili oluyor. Özellikle son 2-3 yıldır bu uygulamayl yapıyorum (Esra).

İzinsiz bir başka arkadaşımızın bedenine asla dokunmamı gerektiğini tuvalete girerken sırayla girmemiz gerektiğini kapıyı çalmamı gerektiğini yani günlük yaşamla ilgili onların kazanması gereken en basit düzeyde onların anlayabileceği şekilde kısa kısa sohbetlerimiz ya da o an olay geliştiği esnada müdahale edip bu tarz konuları onlara söylüyorum (Zeynep).

Kimsenin kimseye hakaret etme, aşağllama ya da kişisel özelliklerine yönelik söylemeye rencide etmeye hakkı olmadı̆̆ını, bunun kimsenin yapamayacağını, olumsuzlaştırma örnekleriyle olumlulaştırma örnekleriyle de yapıyoruz. Bu buna şunu demiş, hikaye anlatıyoruz. Bu kendini nasıl hisseder(Ebru).

Tablo 7: Öğretmenlerin Çocuk Haklarına Yönelik Görüşleri

\begin{tabular}{|c|c|c|c|c|c|c|}
\hline \multirow[b]{3}{*}{ Tema } & \multirow[b]{3}{*}{ Kategoriler } & \multirow[b]{3}{*}{ Kategorilere İlişkin Örnek İfadeler } & \multicolumn{4}{|c|}{ Toplam } \\
\hline & & & \multicolumn{2}{|c|}{ Devlet } & \multicolumn{2}{|c|}{ Özel } \\
\hline & & & : & 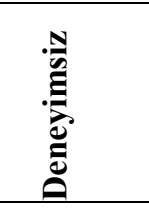 & : & 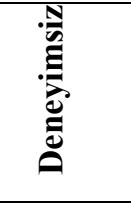 \\
\hline \multirow{5}{*}{ Tanım } & $\begin{array}{l}\text { Temel } \\
\text { Haklar }\end{array}$ & $\begin{array}{l}\text { Yeme-içme-beslenme, yaşama, korunma, } \\
\text { çocukların doğduklarından } 18 \text { yaşına } \\
\text { kadar sahip olduğu haklar, insan } \\
\text { haklarının hepsi geçerli, çocukların } \\
\text { ihtiyaçları onların hakkıdır, eğitim/sosyal } \\
\text { /cinsel yönden bütün çocukların eşit } \\
\text { hakka sahip olması, bakım, evrensel bir } \\
\text { olgu, oyun oynamak }\end{array}$ & $\begin{array}{l}\text { Zeynep } \\
\text { Ebru }\end{array}$ & $\begin{array}{l}\text { Melike(2) } \\
\text { Filiz(2) } \\
\text { Hülya(2) } \\
\text { Kevser }\end{array}$ & $\begin{array}{l}\text { Burcu(4) } \\
\text { Şeyma(3) } \\
\text { Seçil } \\
\text { Hatice }\end{array}$ & $\begin{array}{l}\text { Gizem } \\
\text { Sevda }\end{array}$ \\
\hline & $\begin{array}{l}\text { Bireysel } \\
\text { Haklar }\end{array}$ & $\begin{array}{l}\text { Eğitim, sağlık, giyinme, hayal güçlerine } \\
\text { saygı, ç̧ocuğun kişiliğinin sağlıklı } \\
\text { yetişebilmesi için ona verilmesi gereken } \\
\text { şeyler, çocuğu maddi manevi yönden } \\
\text { desteklemek, çocukları birey olarak kabul } \\
\text { etmek, sevgi, düşünce özgürlüğü, } \\
\text { çocuğun çocukça yaşaması, fiziksel hak, } \\
\text { duygusal hak. }\end{array}$ & $\begin{array}{l}\text { Zeynep } \\
(2) \\
\text { Gamze } \\
\text { Ebru(2) } \\
\text { Esra }\end{array}$ & $\begin{array}{l}\text { Filiz } \\
\text { Melike } \\
\text { Esma } \\
\text { Hülya }\end{array}$ & $\begin{array}{l}\text { Hatice } \\
\text { Burcu(2) } \\
\text { Şeyma(3) } \\
\text { Nilüfer }\end{array}$ & $\begin{array}{l}\text { Meryem } \\
\text { (2) } \\
\text { Sevda(2 } \\
\text { ) Gizem } \\
\text { Ali }\end{array}$ \\
\hline & $\begin{array}{l}\text { Kanuni } \\
\text { Haklar }\end{array}$ & $\begin{array}{l}\text { Hukuktaki kanunlar, çocuklar için } \\
\text { özelleştirilmiş yazılı maddeler, devletin } \\
\text { çocukları korumaya aldığı bir yasa }\end{array}$ & & & & $\begin{array}{l}\text { Ali } \\
\text { Fatma } \\
\text { Sevda }\end{array}$ \\
\hline & $\begin{array}{l}\text { Sosyal } \\
\text { Haklar }\end{array}$ & Gezme-seyahat etme, sosyalleşme & $\begin{array}{l}\text { Zeynep } \\
(2)\end{array}$ & Melike & & \\
\hline & Toplam & & 10 & 12 & 16 & 11 \\
\hline
\end{tabular}

Tablo 7' de görüldüğü üzere okul öncesi öğretmenleri çocuk haklarına yönelik toplamda 49 görüş bildirmişlerdir. Öğretmenlerin çocuk hakları kavramını açıklarken tanım temasına ilişkin 
olarak açıklama yapmışlardır. Tanım temel haklar, kanuni haklar, bireysel haklar ve sosyal haklar olarak dört alt temaya ayrılmıştır. Temel haklar alt temasında devlette ve özelde çalışan öğretmenlerin görüşleri incelendiğinde; devlette çalışan deneyimli öğretmenlerin 2, deneyimsiz öğretmenlerin 7 görüsş, özelde çalışan deneyimli öğretmenlerin 9, deneyimsiz öğretmenlerin 2 görüş bildirdiği belirlenmiştir. Kanuni haklar alt temasında ise sadece özelde çalışmakta olan deneyimsiz öğretmenler 3 görüş bildirmişlerdir. Bireysel haklar alt temasında devlette ve özelde çalışan öğretmenlerin görüşleri incelendiğinde; devlette çalışan deneyimli öğretmenlerin 6 , deneyimsiz öğretmenlerin 4 görüş, özelde ise deneyimli öğretmenlerin 7, deneyimsiz öğretmenlerin 6 görüş bildirdiği saptanmıştır. Sosyal haklar alt temasına ait görüşler incelendiğinde devlette çalışan deneyimli öğretmenlerin 2, deneyimsiz öğretmenlerin 1 görüş bildirdiği, özelde çalışmakta olan öğretmenlerin ise görüş bildirmediği belirlenmiştir.

Öğretmenler çocuk haklarına ilişkin olarak en çok tüm insanların sahip olması gereken temel haklardan bahsetmektedirler. Öğretmenler çocukların bireysel haklarının da olduğunun bilincindedirler ancak bu hakların tam olarak yerine getirilmediğini düşünmektedirler. Bireysel haklar alt temasında daha çok çocuğun duygusal gelişimine yönelik ifadelere yer verildiği görülmektedir. Öğretmenler çocuk haklarının yerine getirilmesinde en büyük payın ailelerde olduğunu belirtmektedirler. Ancak öğretmenlerin çocuk hakları kavramını tanımlamakta yeterli olmadıkları söylenebilir.

Öğretmenlerin çocuk haklarına yönelik görüşleri aşağıda verilmiştir:

...Çocuklarında bir birey ama yetişkinin küçültülmüşü değil kendi yaşıtlarında ve kendi seviyelerinde bir birey oldukların kabul ederek onların da birtakım hakları olduğunu bir yetişkinin var olabildiği gibi benimsemek ve bunları onlara tanımak(Ebru).

Temel haklarını geçersek eğer onları herkes biliyor diye düşünüyorum ama birçok çocuğun bence bize gelene kadar en büyük hakkı kendini ifade etme. Benim şu ana gördügü̈m kadarıyla çocuklar dinlenmemiş bir şey anlatılmamış (Melike).

Çocuk hakları 18 yaşına kadar olan bireylerin sahip oldukları bazı şeyler. Eğitim hakkı gibi yaşama gibi beslenme gibi barınma gibi yani dünyada bütün çocukların aynı haklara sahip olduğunu ve bunun bir sözleşme ile kabul edildiğini hatırliyorum (Filiz).

Tablo 8: Öğretmenlerin Çocuk Haklarına Yönelik Olarak Düzenledikleri Etkinlikler

\begin{tabular}{|c|c|c|c|c|c|c|}
\hline \multirow[b]{3}{*}{ Tema } & \multirow[b]{3}{*}{ Kategoriler } & \multirow[b]{3}{*}{$\begin{array}{l}\text { Kategorilere } \\
\text { Örnek İfadeler }\end{array}$} & \multicolumn{4}{|c|}{ Toplam } \\
\hline & & & \multicolumn{2}{|c|}{ Devlet } & \multicolumn{2}{|c|}{ Özel } \\
\hline & & & 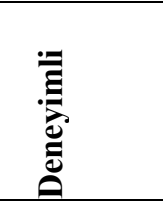 & 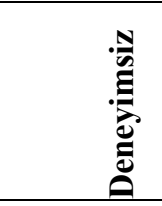 & 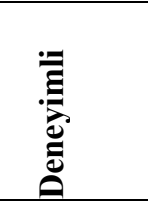 & 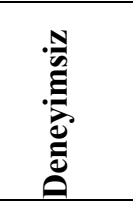 \\
\hline \multirow{2}{*}{$\begin{array}{l}\text { Sinıfiçi } \\
\text { Etkinliklerle } \\
\text { Destekleme }\end{array}$} & $\begin{array}{l}\text { Program } \\
\text { içerisine } \\
\text { yerleştirme }\end{array}$ & $\begin{array}{l}\text { Video, şark1 söyleme, parti } \\
\text { düzenleme, tiyatro, sinema, } \\
\text { hikaye, sohbet etmek, } \\
\text { anlatım şeklinde, resim } \\
\text { yaptırma, sanat etkinliği }\end{array}$ & $\begin{array}{l}\text { Zeynep(4) } \\
\text { Ayşe(3) } \\
\text { Esra } \\
\text { Ebru(2) } \\
\text { Gamze(2) }\end{array}$ & $\begin{array}{l}\text { Kevser(2) } \\
\text { Hülya }\end{array}$ & $\begin{array}{l}\text { Hatice(3) } \\
\text { Seçil }\end{array}$ & Gizem \\
\hline & $\begin{array}{l}\text { Bireysel } \\
\text { uygulamalar }\end{array}$ & $\begin{array}{l}\text { Tüm çocuklara eşit hak ve } \\
\text { süreler tanıma, küçük } \\
\text { sorumluluklar verme }\end{array}$ & $\begin{array}{l}\text { Esra } \\
\text { Ebru }\end{array}$ & Esma & Şeyma & \\
\hline $\begin{array}{l}\text { Farklı } \\
\text { Etkinlikler } \\
\text { Düzenleme }\end{array}$ & $\begin{array}{l}\text { Farklı } \\
\text { kuruluşların } \\
\text { etkinlikleri }\end{array}$ & $\begin{array}{l}\text { ÇOÇA'nın } \quad \text { etkinliğini } \\
\text { düzenleme }\end{array}$ & & & Burcu & $\begin{array}{l}\text { Meryem } \\
\text { Gizem }\end{array}$ \\
\hline
\end{tabular}


UNICEF' in sayfasındaki etkinlik, loblarla özel alan etkinliği
Aile katılım Velilere not gönderme etkinliği
Gamze

Toplam

15

4

6 3

Öğretmenlerin çocuk haklarına yönelik olarak düzenledikleri etkinlik örnekleri sınıf içi etkinliklerle destekleme ve farklı etkinlikler düzenleme olarak iki tema altında toplanmıştır. Tablo 8'de görüldüğü gibi çalışmaya katılan öğretmenler çocuk haklarına yönelik düzenledikleri etkinliklerde sınıf içi etkinliklerle destekleme temasına ait 24 görüş bildirmişlerdir. Sınıf içi etkinliklerle destekleme teması program içerisine yerleştirme ve bireysel uygulamalar olarak iki alt temaya ayrılmıştır. Program içerisine yerleştirme alt temasındaki devlette ve özelde çalışan öğretmenlerin görüşleri incelendiğinde; devlette çalışan deneyimli öğretmenlerin 12, deneyimsiz öğretmenlerin üç görüş, özelde çalışan deneyimli öğretmenlerin dört, deneyimsiz öğretmenlerin 1 görüş bildirdiği belirlenmiştir. Bireysel uygulamalar alt temasında ise devlette çalışan deneyimli öğretmenler iki, deneyimsiz öğretmenler bir görüş bildirirken, özelde çalışan deneyimli öğretmenler bir görüş, deneyimsiz öğretmenler ise görüş bildirmemişlerdir. Farklı etkinlikler düzenleme temasında öğretmenler toplam dört görüş bildirmişlerdir. Farklı etkinlikler düzenleme teması farklı kuruluşların etkinlikleri ve aile katılım etkinliği olarak iki farklı alt temaya ayrılmıştır. Farklı kuruluşların etkinlikleri alt teması incelendiğinde devlette çalışmakta olan öğretmenlerin görüş bildirmediği, özelde çalışan deneyimli öğretmenlerin bir, deneyimsiz öğretmenlerin iki görüş bildirdiği belirlenmiştir. Aile katılım etkinliği alt temasında ise sadece devlette çalışmakta olan deneyimli bir öğretmen görüş bildirmişlerdir.

Öğretmenler genel olarak çocuk hakları ile ilgili özel etkinlikler düzenlemek yerine tüm etkinliklerde çocukların haklara sahip olduğunu belirterek farkındalık kazandırmaya çalışmaktadırlar. Haklarla ilgili belirli gün ve haftalarda çocuk haklarına yönelik etkinliklere daha s1k yer verdikleri görülmektedir. Öğretmenlerin çocuk haklarına yönelik düzenledikleri etkinlere yönelik görüşlerinden alıntılar aşağıda verilmiştir:

...Örneğin oyun oynayacă̆ız, herkese eşit süreler eşit haklar tanırdım. Herkesin birbiri üzerinde hakkı olduğunu kendilerinin de hakları olduğunu anlamalarını sağlardım (Esma).

Önce özel alanı ögrretiyoruz. Bunu çocuklara yönelik loblarla öğretiyoruz. Her oturan kişi kendisine bir lob allyoruz, bu senin özel alanın diyoruz. Sen istemedikçe kimse sana dokunamaz, bu alana kimse karışamaz (Burcu).

...Ekim ayında Dünya Çocuk günü haftasında onların kendi haklarlyla ilgili küçük hikâyelerimiz var mesela sınıf kitaplı̆̆ımızda onlardan okuyoruz. Sanat etkinlikleri yapıyoruz (Zeynep).

... İşte herkesin söz almaya hakkı var, herkesin oyuncakla oynamaya hakkı var. İşte özellikle o günkü olayı paylaşma mantığıyla işte herkesin onu öğrenmeye hakkı var, herkesin dinlemeye hakkı var gibi (Ebru).

Çalışmaya katılan tüm okul öncesi öğretmenleri çocuk hakları ile ihmal ve istismar arasında bir ilişki olduğunu düşünmektedir. Öğretmenler çocukların haklara sahip olduğu hem toplum hem de çocuklar tarafından bilinirse ihmal ve istismara karşı önleyici bir durumun oluşacağını söylemektedirler. Öğretmenlerin çocuk hakları ile ihmal ve istismar arasında ilişki olup olmadığına ilişkin görüşlerinden bazıları aşağıda belirtilmiştir. 
..Hakları bilmeyen ebeveyn çocuğuna çok rahat ihmal ve istismar uygulayabilir. İkisi ilişkili çünkü çocuk haklarında çocuğun ihmal ve istismarını kapsayan bir sürü kural geçiyor. Anne bunu bilmediği için çocuğuna fakında olmadan istismar edebiliyor (Meryem).

...Devlet çocukların sağlık, korunma giyinme gibi bütün haklarını koruyor. Bunların içinde de ihmal ve istismarın olduğunu düşünüyorum. Mesela bir aile çocuğuna iyi bakamıyorsa o çocuğu alıyor bakım evine koyuyor. Böylece çocuğun hakkı olduğu için en azından istismarın önüne geçiliyor (Sevda).

Çocuk hakları gerçekten tümüyle uygulanabilse belki ihmal ve istismar durumu daha azalabilir. Daha olumlu bir çizelge olabilir bu konuda. Yani çocuk hakları konusunda herkes bilinçli olsa diğer konularda da belki bir bilinçlenme olur (Gamze).

\section{Tartışma, Sonuç ve Öneriler}

Bu çalışmada okul öncesi öğretmenlerinin çocuk ihmal ve istismar ile çocuk haklarına yönelik görüşlerinin değerlendirilmesi amaçlanmıştır. Okul öncesi öğretmenlerinin çocuk ihmali hakkındaki düşüncelerini tanım ve çeşitleri alt temalarında ifade ettikleri ve ihmali daha çok sorumluluk ve ilgi kavramları ile bağdaştırdıkları görülmüştür. İhmalin çeşitleri alt temasında verilen cevaplar incelendiğinde ise öğretmenler sırasıyla en çok duygusal, fiziksel, eğitim/eğitimsel, sosyal ve ekonomik ihmale ilişkin ifadelerde bulunmuşlardır. İhmal çeşitlerine bakıldığında fiziksel, duygusal ve cinsel ihmal olarak ayrıldığı görülmektedir. Ancak çalışmaya katılan öğretmenler cinsel ihmale yönelik hiçbir örnek ifadede bulunmamışlardır. Çalıșmaya katılan öğretmenlerin ihmale yönelik fikirleri olduğu ancak net bir tanım yapmakta zorlandıkları söylenebilir. İhmal ve istismar konusunda eğitim alan öğretmenlerin daha açıklayıcı tanımlar yapabildikleri de araştırma sonucunda görülmüştür. Öğretmenlerin ihmal edilen çocuklarda en çok bireysel ve sosyal sorunları gözlemledikleri belirlenmiştir. Bireysel sorunlarına verdikleri örnek ifadelerde çocuklarda gözlemledikleri gelişim aksaklıklarından bahsetmişlerdir. $\mathrm{Bu}$ gelişim aksaklıklarının ailelerin sorumluluklarını yerine getirmediği için oluştuğunu belirtmişlerdir. Bu durum ihmalin tanımında bahsettikleri sorumluluk kavramı ile paralellik göstermektedir. Çocuğa karşı yapmakla yükümlü oldukları sorumluluklar yerine getirilmediğinde bu tür davranış problemleri ile karşılaşılabilir. Sosyal sorunlarda ise çevresine karşı göstermiş olduğu olumsuz davranış örneklerini ifade etmişlerdir. İhmal edilen çocuktaki davranışların ise aileden kaynaklı olduğunu düşünmektedirler. İhmalin tanımında ailenin ya da çocuğa bakmakla yükümlü olan kişinin çocuğun temel ihtiyaçlarını yerine getirmemesinden bahsedilmektedir. Öğretmenlerin bu konudaki ifadeleri ihmal tanımı ile uyuşmaktadır. Keser, Odabaș ve Elibüyük (2010) ise toplumda çocuk ihmali ve istismarı konusunda bilgi eksikliklerinin olduğunu ve bu eksikliklerin giderilmesi için uygulanan eğitim programlarının sayısının yetersiz olduğunu ifade etmektedir. Ayrıca yapılan araştırmalar öğretmenlerin büyük oranda ihmal ve istismara yönelik bir eğitim almadıklarını ve bu konuda bilgilendirmeye ihtiyaç duyduklarını göstermektedir (Çakar \& Okuyan, 2017; Dilsiz \& Mağden, 2015; Gallagher-Mackay, 2014; Münger \& Markström, 2019; Sağır \& Gözler, 2013; Toros \& Tiirik, 2016). Aksel ve Irmak (2015) ise öğretmenlerin kısa süreli de olsa alınan hizmet içi eğitimlerden yararlandıklarını belirlemiştir. Yapılan araştırmalarda öğretmenlerin üniversite eğitimleri süresince ve hizmet içi eğitimlerle sürekli olarak çocuk ihmal ve istismarı konusunda eğitilmeleri ve bilgilerinin yüksek düzeyde tutulması gerektiği ifade edilmektedir (Goldman, 2005; McIntyre, 1990; McKee \& Dillenburger, 2009).

Öğretmenlerin istismara ilişkin görüşleri incelendiğinde; tanım temasında en çok sırasıyla güç kullanmak, duygusal baskı, faydalanmak ve zarar vermek alt temasına ilişkin ifadelerde bulundukları belirlenmiştir. Öğretmenlerin istismar hakkında görüşleri olduğu ancak tanım yapmakta zorlandıkları görülmüştür. Çeşitlerine temasına verdikleri cevaplara bakıldığında fiziksel, duygusal ve cinsel istismara ilişkin örnek ifadelerde bulunurlarken ekonomik, sosyal, psikolojik ve madde bağımlılığı gibi istismar çeşitleri olduğunu ifade eden öğretmenler de vardır. Öğretmenlerin en çok 
fiziksel istismar hakkında örnek ifadede bulunması fiziksel istismarın en kolay farkedilen istismar çeşidi olması ile ilişkili olabilir. Cinsel istismara yönelik verilen örneklere bakıldığında cinsel eğitim vermemek ifadesi ile karşılaşılmaktadır. Ancak cinsel eğitim vermemek cinsel ihmal tanımı içerisinde ele alınmaktadır. Bu durum ihmal çeşitlerinde de karşımıza çıkan, öğretmenlerin cinsel ihmal ve istismar ayrımını yapamadıkları sonucunu desteklemektedir. Márquez-Flores ve arkadaşları (2016) öğretmenlerin cinsel istismar konusunda yanlış bilgilerinin olduğunu belirlemişlerdir.

Okul öncesi öğretmenlerinin görüşlerine göre; istismara uğradığı düşünülen çocuklarda en çok içselleştirme davranış problemleri ardından dışsallaştırma davranış problemleri olduğu gözlemlenmiştir. İçselleştirme davranış problemlerinde çocuklarda konuşma geriliği, içe kapanıklılık, fevri davranışlar, kendini suçlama gibi davranışlar gözlemlendiği; dışsallaştırma davranış problemlerinde ise çocuklarda görülen şiddet içerikli davranışlar ve yere tükürmek gibi olumsuz davranışlar gözlemlendiği belirtilmiştir. Gözlemlenen bu belirtiler çocuklara yönelik istismarın belirlenmesinde öğretmenlerin önemli bir konumda yer aldığını göstermektedir. Pekdoğan ve Bozgün (2018) de öğretmenlerin istismar konusunda bilgi düzeylerinin yüksek olduğunu, fakat ihmal konusunda pek fazla bilgi sahibi olmadıklarını ifade etmektedirler. Yapılan araştırmalar, öğretmenlerin çocuk ihmali ve istismarına yönelik belirtilerle karşılaştıklarını, ancak özellikle aile içi şiddete tanık olan çocukların gösterdikleri belirtileri anlamakta zorlandıklarını belirtmektedir (Hodgkinson \& Baginsky, 2000; Usakli, 2012). King ve Scott (2014) öğretmenlerin istismara maruz kalan çocukları belirleseler de onlarla nasıl iletişim kuracaklarını bilmediklerini de ifade etmektedirler. Yapılan çalışmalar çocuk istismarına ilişkin eğitim alan öğretmenlerin eğitim almayan öğretmenlere göre çocuk istismarına ilişkin daha fazla bildirim yaptıklarını belirlemişlerdir. (Özyürek, Çetin ve Yıldırım, 2018; Goebbels, Nicholson, Walsh \& De Vries, 2008). Yanowitz, Monte ve Tribble (2003) ise öğretmenlerin fiziksel ve duygusal istismarın sonucunda çocuğun sınıftaki davranış değişikliklerine yönelik görüşlerini inceledikleri araştırma sonucunda, genellikle çocukların benlik saygısının ve akademik başarısının azaldığı, saldırganlığın arttığı ve sosyal ilişkilerde gerileme olduğunu ifade ettiklerini saptamışlardır. Genellikle yetişkinlerin kendilerine dokunmasından tedirgin olmakta, kolaylıkla yalan söyleyebilmektedirler. Başka bir çocuğun ağlamasından etkilenmekte ancak kendileri çok kolay ağlayamamaktadırlar. Davranışlarında iki uç görülmekte, ya çok fazla saldırgan olabilmekte ya da içe dönük olmaktadırlar. Yenibaş ve Şirin (2007) de cinsel istismara maruz kalmış çocuklarda uysal olmanın veya fazla hırçınlaşmanın yaygın görülen davranışşekilleri olduğunu ifade etmektedir.

Öğretmenlerin ihmal ve istismar hakkında uyguladıkları etkinliklerin cinsel farkındalığa yönelik, sosyal farkındalığa yönelik ve çocuk haklarına yönelik olduğu belirlenmiştir. En fazla cinsel farkındalığa ilişkin etkinliklerin uygulanması çocuklara yönelik cinsel istismar vakalarının artması ile ilgili olabilir. Ancak öğretmenlerin cinsel ihmal ve istismarı ayırdedememeleri etkinlikler konusunda yeterli düzeyde bilgi sahibi olup olmadıkları konusunda da düşündürmektedir. Öğretmenler çocukların ihmal ve istismara karşı farkındalık kazanmaları için haklarının bilincinde olmaları gerektiğini düşünmektedirler. Bu sebeple çocuk haklarına yönelik etkinliklerin ihmal ve istismara karşı önleyici olabileceğini ya da bu duruma maruz kalan çocukların haklarının bilincinde olarak kendini daha rahat ifade edebileceğini düşünmektedirler. Ayrıca istismara maruz kalmış olan çocuğu ve aileyi destekleyebilmeleri ve toplumu eğitebilmeleri açısından öğretmenler çok önemlidir (Akacan, 2012). Aynı şekilde ihmal ve istismar eğitimine çocuk haklarından başlanması gerektiğini söyleyen öğretmenler de bulunmaktadır. Öğretmenlerin çocuk haklarının tanımına verdikleri cevaplar incelendiğinde en çok bireysel haklar ve temel haklar üzerinde durdukları görülmüştür. Çalı̧̧maya katılım gösteren öğretmenler ilk olarak herkesin sahip olması gereken temel haklardan bahsetmektedirler. Çocukların bireysel haklarını ise daha çok duygusal gelişimini destekleyici bir tutum içerisinde ele almışlardır. Öğretmenlerin çocuk haklarına yönelik düzenledikleri etkinliklere dair ifadeleri incelendiğinde; çocuk haklarına yönelik özel etkinlikler düzenlemek yerine tüm etkinliklerde çocuklara haklarının var olduğunu belirterek onlara söz alma hakkı, kendini ifade etme 
hakkı tanıyarak bu konuda farkındalık kazandırmaya çalışmaktadırlar. Farklı kuruluşlara ait etkinlikleri yapan öğretmenler de bulunmaktadır. Aile katılımına yönelik etkinlik düzenlediğini belirten bir öğretmen bulunmaktadır. Görüşmeler incelendiğinde bazı öğretmenler, ihmal ve istismar hakkında bilinçlenmek için çocuk haklarının bilinmesi gerektiğini belirtmişlerdir. Yapılan çeşitli araştırmalar da öğretmenlerin ve okul yöneticilerinin Çocuk Hakları Sözleşmesi'ni çok fazla bilmediklerini, ders programlarında çok fazla yer vermediklerini ve yapılan uygulamaların istenilen düzeyde olmadığını göstermektedir (Ersoy, 2012; Öztürk \& Doğanay, 2017; Shumba, 2003). Banko (2017) yaptığı araştırmada, öğretmenlerin çocuk hakları konusunda istekli olduklarını belirttiklerini, ancak sınıf içi etkinliklerinde görüşleri ile orantılı davranışlar sergilemediklerini ifade etmektedir. Banko (2017)'nun belirttiğine göre; okul öncesi öğretmenleri oyun hakkını savunmakta, ancak çocuklara oyun oynamaları için yeterli firsatlar sunmamaktadırlar. Ancak yapılan çeşitli araştırmalar ise çocuk haklarının öğretiminde anadili, hikaye, drama ve oyun gibi somutlaştırılmış çeşitli etkinliklerden yararlanılabileceğini ve öğretmenin rol model olması gerektiğini göstermektedir (Howe \& Covell, 2005; Kozikoğlu, 2018; Neslitürk \& Ersoy, 2007; Topçu, 2019). Çocuk haklarının okul öncesi dönemde öğretilmesiyle beraber çocuklar, hakların neler olduğunu, istek ve gereksinim ile haklar arasındaki farkı, tüm çocukların aynı haklara sahip olduğunu, istismar içeren durumların neler olduğunu ve kendi davranışlarının başkaları üzerindeki etkisini öğrenebilmektedir. Turupcu ve Gültekin Akduman (2015) çocuk haklarının herkes tarafından bilinmesi, korunması ve bu haklara saygı gösterilmesinin en doğru şekilde eğitim yoluyla öğretildiğini ifade etmektedir. Church ve Bateman (2019) öğretmenlerin sınıf içi ve sınıf dışı etkinliklerinde çocuk temelli etkinliklerle çocuk hakları eğitimi verebileceklerini belirtmektedirler. Ancak öğretmen ne kadar çok çocuk haklarından bahsederse bahsetsin, kendisi model olmuyorsa, öğrettikleri geri planda kalacaktır. Bu nedenle öğretmenlerin çocuk haklarını öğretirken rol model olması gerekmektedir. Ancak aile de bilinçli değil ise okulda öğretilmeye çalışılanın da yeterli olmayacağı da açıktır. Nitekim Ersoy (2012) velilerin çocuk haklarını yeterince bilmediklerini ve çocukların da haklarını yeterince öğrenemediklerini belirtmektedir. Literatürde yer alan çalışmalarla, aile eğitimi ve katılımının çocukların gelişimlerine ve eğitimlerine katkı sağladığını göstermektedir (Bağçeli-Kahraman \& Başal, 2015; Benner, Boyle \& Sadler, 2016; Bruïnea, Willemse, D’Haem, Griswold, Vloeberghs \& Eynde, 2014; Sheridan, Knoche, Kupzyk, Edwards \& Marvin, 2011). Seyhan ve Cansever (2017) de öğretmenlerin aileler ve çocuklar için çeşitli eğitim materyalleri hazırlayarak çocuk haklarını öğretmesi gerektiğini ifade etmektedir. Bu nedenle aile eğitim ve katılım çalışmalarının ailelerin farkındalığının artması açısından önemli olduğu düşünülmektedir.

Öğretmenlerin çocuk haklarına yönelik uygulamalara yeteri kadar yer vermedikleri ve çocuk hakları konusunda bilgilerinin sınırlı düzeyde kaldığı görülmektedir. Ayrıca yetişkinlerin çocuk haklarını bildiği takdirde ihmal ve istismara yönelik davranışlarının azalacağını, çocukların kendi haklarını bildiğinde bu tür olumsuz durumlarda kendini savunabileceğini belirtmektedirler. $\mathrm{Bu}$ durumda öğretmenlerin çocuk ihmali ve istismarı ile çocuk hakları arasındaki ilişkiden yola çıkarak öncelikle çocuklara çocuk haklarını ve kendini ihmal ve istismardan koruma yollarını öğretmeleri gerektiği düşünülmektedir. Çocukların mutluluğu için çocuk haklarına inanan ve bu konuda iyi eğitim almış öğretmenlere ihtiyaç vardır. Bu durumun gerçekleşebilmesinde öğretmen adaylarına öğretmenlik eğitimleri süresince çocuk hakları ile ihmal ve istismara yönelik bir eğitimin verilmesinin ve öğretmenlere hizmet içi eğitimlerin verilmesi gerektiği düşünülmektedir. Bu eğitim ve hizmetlerin içeriklerinin çocuklara yönelik uygulanabilecek etkinliklerle birleştirilmesinin öğretmenlerin daha kolay ve rahat eğitim vermelerinde önemli olduğu da söylenebilir. Bu araştırma kapsamında sadece öğretmenlerin görüşleri ele alınmıştır. Öğretmenlerin sınıf içi uygulamalarını da içine alan çalışmalar yapılabilir. Çocuk ihmal ve istismarından çocukların korunmasına yönelik ve çocuk haklarını da içeren deneysel çalışmaların yapılması, bu konunun okul öncesi eğitimde nasıl geliştirilebileceğinin görülmesi açısında önemlidir. Araştırmanın daha farklı bölgelerde çalışan okul öncesi öğretmenleri ile yapılamasının da önemli olduğu düşünülmektedir. 


\section{Kaynakça}

Akacan, B. (2012). Ortaöğretim okullarında görev yapan eğitimcilerin çocuk istismarına ilişkin görüşleri. Turkish International Journal of Special Education and Guidance \& Counselling (TIJSEG) 1(2), 37-53

Akar, H. (2017). Durum çalışması. (Ed. A. Saban ve A. Ersoy)., Eğitimde nitel araşstırma desenleri içinde. (s. 139-176), Anı Yay.

Aksel, E. Ş.,\& Irmak, T. Y. (2015). Çocuk cinsel istismarı konusunda öğretmenlerin bilgi ve deneyimleri. Ege Eğitim Dergisi, 16(2), 373-391. https://doi.org/10.12984/eed.60194

Aral, N., \& Gürsoy, F. (2001). Çocuk hakları çerçevesinde çocuk ihmal ve istismarı. Milli Eğitim Dergisi, 151(5), 27-54.

Bağçeli Kahraman P.,Başal H.A. (2015). Theeffects of preschool education program with enriched parental involvement dimension on school readiness of 5-6 year old children. Asosjournal,13(3), 1-10.

Banko, Ç. (2017). Okul öncesi ögretmenlerinin çocuk haklarına ilişkin tutum, davranış ve görüşlerinin incelenmesi. Yayımlanmamış Yüksek Lisans Tezi, Hacettepe Üniversitesi Eğitim Bilimleri Enstitüsü, Ankara.

Bee, H. L. (1995). The growing child. Harpercollins College Division.

Benner, A. D., Boyle, A. E., \& Sadler, S. (2016). Parental involvement and adolescents' educational success: Theroles of prior achievement and socio economic status. Journal of Youth and Adolescence, 45(6), 1053-1064. https://doi.org/10.1007/s10964-016-0431-4

Bilginer, C., Hesapcioglu, S. T., \& Kandil, S. (2013). Sexualabuse in childhood: A multidimensional look from the viewpoint of victims and perpetrators. The Journal of Psychiatry and Neurological Sciences, 26, 55-64.

Bourke, A.,\&Maunsell, C. (2016). 'Teachers matter': theimpact of mandatory reporting on teacher education in Ireland. Child Abuse Review, 25(4), 314-324. https://doi.org/10.1002/car.2379

Bozgun, K., \& Pekdoğan, S. (2018). Öğretmenlerin çocuk ihmali ve istismarı hakkındaki görüşlerinin incelenmesi. MANAS Sosyal Araştırmalar Dergisi,7(2), 433-443. https://doi.org/10.33417/tsh.643971

Breadkamp, S. \& Copple, C. (2002). Developmentally appropraite practice in early childhood programs. National Association for The Education of Young Children.

Bruïne, E. J.,Willemse, T. M., D’Haem, J., Griswold, P., Vloeberghs, L. \&Eynde S. V. (2014) Preparing teacher candidates for family-school partnerships, European Journal of Teacher Education, 37(4), 409-425. https://doi.org/10.1080/02619768.2014.912628

Buckley, H. \&McGarry, K. (2011). Child protection in primary schools: a contradiction in termsor a potential opportunity? Irish Educational Studies, 30(1), 113-128. https://doi.org/10.1080/03323315.2011.535979

Creswell, J. W., \& Poth, C. N. (2016). Qualitative inquiry and research design: Choosing among five approaches. Sage Publications.

Çakar, F. S., \& Okuyan, H.Y. (2017). Öğretmen adaylarının çocuk istismarı ve ihmaline ilişkin görüşleri. Mehmet Akif Ersoy Üniversitesi Eğitim Fakültesi Dergisi, 44, 250-275. https://doi.org/10.21764/maeuefd.332243 
Dereobal1, N., Karadağ, S. Ç., \& Sönmez, S. (2013). Okulöncesi eğitim öğretmenlerinin çocuk istismarı ihmali şiddet ve eğitimcilerin rolü konusundaki görüşleri. Ege Eğitim Dergisi, 14(1), 50-66. https://doi.org/10.1501/egifak_0000001078

Dilsiz, H.,\&Mağden, D. (2015). Öğretmenlerin çocuk istismar ve ihmali konusunda bilgi ve risk tanıma düzeylerinin tespit edilmesi. Hacettepe Üniversitesi Sağllk Bilimleri Fakültesi Dergisi, 1, 678-694. https://doi.org/10.17681/hsp.79915

Durmuşoğlu-Saltalı, N. (2015). Çocuk istismarı ve ihmali. S. Sunay Yıldırım-Doğru (Ed.), Çocuk haklarl ve koruma içinde (s. 61-120). (3. Bask1). Eğiten Kitap.

Erbay, E. (2013). Çocuk hakları. Yeni İnsan Yayınevi.

Ersoy, A. F. (2012). Vatandaşlık eğitiminde ihmal edilen bir alan: evde ve okulda çocuk haklarının eğitimi. International Online Journal of Educational Sciences, 4(2),359-376

Gallagher-Mackay, K. (2014). Teachers' duty to report child abuse and neglect and the paradox of noncompliance: Relational theory and "compliance" in the human services. Law \& Policy, 36(3), 256-289. https://doi.org/10.1111/lapo.12020

Goebbels, A.F.G., Nicholson, J.M., Walsh, K. \& De Vries, H. (2008). Teachers' reporting of suspected child abuse and neglect: Behavior and determinants. Health Education Research, 23(6), 941-951. https://doi.org/10.1093/her/cyn030

Goldman, J.D.G. (2005). Student teachers' learning about child sexual abuse strategies for primary school: An exploratory study of surface and deep learning. Sex Education: Sexuality, Society and Learning, 5(1), 79-92. https://doi.org/10.1080/1468181042000301902

Gökler, R. (2009). Okullarda akran zorbalı̆̆ı. Uluslararası Insan Bilimleri Dergisi, 6 (2), 511-537.

Hodgkinson, K.,\&Baginsky, M. (2000). Child protection training in school-based initial teacher training: A survey of school-centred initial teacher training courses and their trainees. Educational Studies, 26(3), 269-279. https://doi.org/10.1080/03055690050137105

Howe, R. B.,\&Covell, K. (2005). Empowering children: Children's rights education as a pathway to citizenship. University of Toronto Press. https://doi.org/10.3138/9781442674387

Kenny, M. C. (2004). Teachers' attitudes toward and knowledge of child maltreatment. Child Abuse\&Neglect, 28(12), 1311-1319. https://doi.org/10.1016/j.chiabu.2004.06.010

Kenny, M.C. \&McEachern, A.G. (2008). Reporting suspected child abuse: A pilot comparison of middle and high school counselors and principals. Journal of Child Sexual Abuse, 11(2), 5975. https://doi.org/10.1300/j070v11n02_04

Keser, N., Odabaş, E., \& Elibüyük, S. (2010). Ana-babaların çocuk istismarı ve ihmali konusundaki bilgi düzeylerinin incelenmesi. Türkiye Çocuk Hastalıklarl Dergisi, 4(3), 150-157. https://doi.org/10.33417/tsh.643971

King, C. B., \& Scott, K. L. (2014). Why are suspected cases of child maltreatment referred by educators so often unsubstantiated?. Child Abuse \& Neglect,38(1), 1-10. https://doi.org/10.1016/j.chiabu.2013.06.002

Kozikoğlu, İ . (2018). Okul öncesi öğretmenlerinin çocuk hakları ve çocuk katılım hakkına ilişkin görüşlerinin incelenmesi. Cumhuriyet Uluslararası Eğitim Dergisi, 7 (4), 408427. https://doi.org/10.24130/eccd-jecs.1967201932166

Kucuk, S. (2016) Analyses of child sex abuse cases in turkey: Aprovincial case. Journal of Child Sexual Abuse, 25,3: 262-275. https://doi.org/10.1080/10538712.2016.1153557 
Kurtoğlu, M. (2016). Çocuk bu ihmale gelmez. Nesil Basım Yayın.

Márquez-Flores, M. M., Márquez-Hernández, V. V., \& Granados-Gámez, G. (2016). Teachers' knowledge and beliefs about child sexual abuse. Journal of Child Sexual Abuse, 25(5), 538555. https://doi.org/10.1080/10538712.2016.1189474

McIntyre, T. (1990). Theteacher's role in cases of suspected child abuse. Education and Urban Society, 22(3), 300-306.

McKee, B.E., \&Dillenburger, K. (2009). Child abuse and neglect: Training needs of student teachers. International Journal of Educational Research, 48, 320-330. https://doi.org/10.1016/j.jier.2010.03.002

Miles, M. B., \&Huberman, M. (1994). Qualitative data analysis: An expanded sourcebook. Sage.

Münger, A. C., \& Markström, A. M. (2019). School and child protection services professionals' views on the school's mission and responsibilities for children living with domestic violence-tensions and gaps. Journal of Family Violence, 34(5),385-398. https://doi.org/10.1007/s10896-019-00035-5

Neslitürk, S., \& Ersoy, A. (2007). Okulöncesi öğretmen adaylarının çocuk haklarının öğretimine ilişkin görüşleri. Eğitimde Kuram ve Uygulama, 3(2), 245-257. https://doi.org/10.17244/eku.347789

Oral, Ü. K., Engin, P., \& Büyükyazıcı, Z. (2010). Türkiye'de çocuk istismarı ve aile içi şiddet araştırması özet raporu. UNICEF, https://www.unicef.org/turkey/raporlar/t\%C3\%BCrkiyede-\%C3\%A7ocuk-istismari-veaile-i\%C3\%A7i-\%C5\%9Fiddet-ara\%C5\%9Ftirmasi-\%C3\%B6zet-raporu-2010.

Öztürk, A.,\& Doğanay, A. (2017). Çocuk hakları temelli okul ölçeğinin geliştirilmesi. Trakya Üniversitesi Sosyal Bilimler $\quad$ Dergisi, 19(1), https://doi.org/10.21550/sosbilder.288966

Özyürek, A., Çetin, A., \& Yıldırım, R. (2018). Aile Hekimi ve Öğretmenlerin Çocuk İhmal ve İstismarı Konusundaki Görüş ve Tutumları. Itobiad: Journal of the Human \& Social Science Researches, 7(1), 436-453. https://doi.org/10.17719/jisr.2019.3277

Pears, K. C., Kim, H. K., \& Fisher, P. A. (2008). Psychosocial and cognitive functioning of children with specific profiles of maltreatment. Child Abuse \& Neglect, 32(10), 958-971. https://doi.org/10.1016/j.chiabu.2007.12.009

Polat, O. (2007). Tüm boyutlarıyla çocuk istismarı 1, Seçkin Yayıncılık.

Sağır, M. \&Gözler, A.( 2013). Sınıf öğretmenlerinin çocuk istismarı ve ihmaline yönelik görüşleri ve farkındalık düzeyleri. Türkiye Sosyal Politika ve Çalışma Hayatı Araştırmaları Dergisi, 3 (5), 67-102. https://doi.org/10.17719/jisr.2017.1687

Seggie, F. N. ve Bayyurt, Y. (2015). Nitel araştırma: Yöntem, teknik, analiz ve yaklaşımları. Anı Yayıncilik

Seyhan, G. B.,\& Cansever, B. A. (2017). Öğretmen adaylarının “çocuk hakları” na ilişkin algılarının materyal tasarımları ve görüşleri çerçevesinde incelenmesi. Mehmet Akif Ersoy Üniversitesi Ĕ̈itim Fakültesi Dergisi, 1(41), 98-119. https://doi.org/10.21764/efd.40550

Sheridan, S. M.,Knoche, L. L., Kupzyk, K. A., Edwards, C. P., \&Marvin, C. A. (2011). A randomized trial examining the effects of parent engagement on early language and literacy: The Getting Ready intervention. Journal of School Psychology, 49(3), 361-383. https://doi.org/10.1016/j.jsp.2011.03.001 
Shumba, A. (2003). Children's rights in schools: what do teachers know?.Child Abuse Review. 12, 251-260. https://doi.org/10.1002/car.800

Şallı, D. (2017). Okul öncesi öğretmenlerinin çocuk hakları ile ilgili görüşleri. Eğitim ve Öğretim Araştırma Dergisi Journal of Research in Education and Teaching (JRET), 6(2), 80-87. https://doi.org/10.14686/buefad.310566

Topçu, B. (2019). Yaratıcı drama temelli çocuk hakları programının geliştirilmesi ve uygulanması. Yayımlanmamış Yüksek Lisans Tezi, Gaziantep Üniversitesi Eğitim Bilimleri Enstitüsü, Gaziantep.

Topçu, S. (2009). Silinmeyen izler çocuk, genç ve engellilerin istismar ve ihmali. Phoenix.

Toros, K.,\&Tiirik, R. (2016). Preschool teachers' perceptions about and experience with child abuse and neglect. Early Childhood Education Journal, 44(1), 21-30. https://doi.org/10.1007/s10643-014-0675-0

Turupçu, A.,\& Gültekin Akduman, G. (2015). Okul öncesi eğitim ve çocuk hakları. (Ed. G. Uyanık Balat), Okul Öncesi Ĕgitime Giriş kitabı içinde (ss. 235-252). Nobel Akademik Yayıncılık.

Usakli, H. (2012). The school counselors' ideas on features, determinant and intervention on child negligence and abuse cases. Online Submission, 2(3), 63-74.

Uçuş, Ş.,\& Şahin, A. E. (2012). Çocuk hakları sözleşmesine yönelik öğretmenlerin ve okul yöneticilerinin görüşleri. Adnan Menderes Üniversitesi Ĕ̈itim Fakültesi Ĕgitim Bilimleri Dergisi, 3 (1), 25-41. https://doi.org/10.21565/ozelegitimdergisi.446598

Üstündağ, A., Şenol, F., \& Mağden, D. (2015). Ebeveynler Çocuk İstismarına Yönelik Bilgi Düzeylerinin Belirlenmesi ve Bilinçlendirilmesi. Hacettepe Üniversitesi Sağllk Bilimleri Fakültesi Dergisi, 1, 212-227. https://doi.org/10.21020/husbfd.103913

Walsh, K. M.,Farrell, A. M., Schweitzer, R., \&Bridgstock, R. S. (2005). Critical factors in teachers' detecting and reporting child abuse and neglect: Implications for practice. Final report prepared for the abused child trust. Queensland University of Technology. https://doi.org/10.1177/1476718x06059790

Yalçın, H., Koçak, N., \& Duman, G. (2014). Anne babaların çocuk istismarıyla ilgili tutumlarının incelenmesi. Karamanoğlu Mehmetbey Üniversitesi Sosyal Ve Ekonomik Araştırmalar Dergisi, 3, 137-143. https://doi.org/10.18493/kmusekad.21268

Yanowitz, K. L., Monte, E., \&Tribble, J. R. (2003). Teachers' beliefs about the effects of child abuse. Child Abuse \& Neglect,27(5), 483-488. https://doi.org/10.1016/s01452134(03)00033-4

Yenibaş, R.,\& Şirin, A. (2007). Ailede çocuğun istismarı ve umutsuzluk. Nobel Yayıncılık.

Yıldırım- Doğru, S. (2015). Yasal düzenlemeler. S. Sunay Yıldırım-Doğru (Ed.), Çocuk Haklarl ve Koruma içinde (s. 61-120). (3. Bask1). Eğiten Kitap.

Yıldırım, A., \& Şimşek, H. (2011). Sosyal bilimlerde nitel araştırma yöntemleri. Seçkin Yayıncılık.

Yin, R. K. (2013). Validity and generalization in future case study evaluations. Evaluation, 19(3), 321-332. https://doi.org/10.1177/1356389013497081 